\title{
The Impact of System Integration on System Costs of a Neighborhood Energy and Water System
}

\author{
Els van der Roest ${ }^{1,2, *}$, Theo Fens ${ }^{3}$, Martin Bloemendal ${ }^{1,2}$, Stijn Beernink ${ }^{1,2}$, Jan Peter van der Hoek ${ }^{2,4}$ \\ and Ad J. M. van Wijk 1,5 \\ 1 KWR Water Research Institute, Department of Sustainability \& Transitions, Groningenhaven 7, \\ 3430 BB Nieuwegein, The Netherlands; martin.bloemendal@kwrwater.nl (M.B.); \\ stijn.beernink@kwrwater.nl (S.B.); A.J.M.vanWijk@tudelft.nl (A.J.M.v.W.) \\ 2 Faculty of Civil Engineering and Geosciences, Delft University of Technology, Stevinweg 1, \\ 2638 CN Delft, The Netherlands; j.p.vanderhoek@tudelft.nl \\ 3 Economics of Infrastructures Section, Delft University of Technology, Jaffalaan 5, \\ 2638 BX Delft, The Netherlands; t.w.fens@tudelft.nl \\ 4 Waternet, Korte Oudekerkerdijk 7, 1096 AC Amsterdam, The Netherlands \\ 5 Department of Process and Energy, Delft University of Technology, Leeghwaterstraat 39, \\ 2638 CB Delft, The Netherlands \\ * Correspondence: E.vanderRoest@tudelft.nl
}

Citation: van der Roest, E.; Fens, T.; Bloemendal, M.; Beernink, S.; van der Hoek, J.P.; van Wijk, A.J.M. The Impact of System Integration on System Costs of a Neighborhood Energy and Water System. Energies 2021, 14, 2616. https://doi.org/ $10.3390 /$ en14092616

Academic Editor: Luca Gonsalvi

Received: 3 April 2021

Accepted: 23 April 2021

Published: 3 May 2021

Publisher's Note: MDPI stays neutral with regard to jurisdictional claims in published maps and institutional affiliations.

Copyright: (c) 2021 by the authors. Licensee MDPI, Basel, Switzerland. This article is an open access article distributed under the terms and conditions of the Creative Commons Attribution (CC BY) license (https:/ / creativecommons.org/licenses/by/ $4.0 /)$.

\begin{abstract}
The fossil-based energy system is transitioning towards a renewable energy system. One important aspect is the spatial and temporal mismatch between intermitted supply and continuous demand. To ensure a reliable and affordable energy system, we propose an integrated system approach that integrates electricity production, mobility, heating of buildings and water management with a major role for storage and conversion. The minimization of energy transport in such an integrated system indicates the need for local optimization. This study focuses on a comparison between different novel system designs for neighborhood energy and water systems with varying modes of system integration, including all-electric, power-to-heat and power-to-hydrogen. A simulation model is developed to determine the energy and water balance and carry out economic analysis to calculate the system costs of various scenarios. We show that system costs are the lowest in a scenario that combines a hydrogen boiler and heat pumps for household heating; or a power-to-X system that combines power-to-heat, seasonal heat storage, and power-to-hydrogen ( $2070 € /$ household/year). Scenarios with electricity as the main energy carrier have higher retrofitting costs for buildings (insulation + heat pump), which leads to higher system costs (2320-2370 $€$ /household/year) than more integrated systems. We conclude that diversification in energy carriers can contribute to a smooth transition of existing residential areas.
\end{abstract}

Keywords: energy system analysis; HT-ATES; hydrogen; local optimization; sector-coupling; storage; system integration

\section{Introduction \\ 1.1. Motivation}

In 2018 , modern renewable energy production accounted for $11 \%$ of the total world energy consumption [1]; in Europe, it was 18\% [2]. The European ambition is to strive towards climate neutrality in 2050 [3]. Our future energy systems will thus be very different from current systems, with clear shifts to intermittent renewable resources [4]. Furthermore, energy systems will become more decentralized and multidirectional, with energy production closer to the energy consumers, especially in the urban environment $[5,6]$. More local production reduces the transport of energy and thus reduces the need for reinforcement of the energy infrastructure. These changes come with challenges to keep the system reliable and affordable while increasing the share of clean energy. Energy 
conversion and storage will be essential to overcome the temporal and spatial mismatch between demand and supply. Hence, there is a need for an integrated energy system, which in the EU strategy on energy system integration is defined as " ... the coordinated planning and operation of the energy system 'as a whole', across multiple energy carriers, infrastructures, and consumption sectors" [7].

This definition of system integration is related to the principle of sector-coupling, which means that different sectors, such as electricity, heat and mobility, are integrated into one system [8]. In this paper, we mainly use the term system integration to describe our approach, in which sector-coupling combined with conversion and storage are essential. We refer to sector-coupling in specific cases when the term describes more precisely what we mean.

While system integration is necessary at all levels of the energy system, in this study, we will focus on the neighborhood level in the built environment. In neighborhoods with increasing shares of decentralized energy production and different energy demands [9], system integration could be very useful. To avoid energy transportation costs, it is sensible to try to find a balance of the system as much as possible on a local scale, also known as local optimization. Our future neighborhoods will probably have production peaks from photovoltaic systems on roofs that need to be dispatched, while in winter, there is a peak in demand due to the low efficiency of electric air sourced heat pumps installed for heat production. These peaks cause pressure on the electricity network infrastructure. A simple solution would be to reinforce the network infrastructure to enable transport of these amounts of electricity, but still, there will be times when demand and supply do not match, either spatially or temporally. Thus, energy storage will become an inevitable part of the energy system, including the conversion of excess electricity at times of oversupply [10-12]. By coupling different sectors, such as the electricity, heat and transport sector, it is possible to create a more integrated system and increase the amount of local use of renewable energy [8,12,13].

The same line of reasoning can be applied to water. Because of climate change, we need to adapt our environments to deal with both inundation and droughts. Again, there is a challenge to have enough water at the right place and at the right time. By storing rainwater at times of abundance, we could use it during periods of water scarcity. This paper gives an overview of how we could store and use (rain)water locally. Without the need to be completely independent of the water distribution network, the water needs of a neighborhood could partially be fulfilled by its own rainwater storage and distribution system [14].

\subsection{Literature Research}

The focus of this paper is on different designs for integrated energy and water systems for neighborhoods. There is ongoing research into integrated neighborhood energy systems with sector-coupling and decentralized energy production. A distinction can be made between studies that mostly focus on power-to-gas [8,15-18], power-to-heat [19-22], or both [23-28]. The power-to-gas studies couple the transport and electricity sectors by either focusing on fuel cell electric vehicles FCEV [15-17] or including power-to-fuel [8]. These studies mainly show the potential of FCEV for energy storage and production $[15,16]$ or for sector-coupling of the power and transport sector to deal with surpluses of electricity and show the importance of a high spatial resolution for these calculations [17]. Nastasi and Lo Basso (2016) did consider power-to-hydrogen, especially for application in the heat and electricity sector, by adding hydrogen to CHP units and gas-driven heat pumps or for synthetic methane [18]. They found that hydrogen can fulfill 5-35\% of the energy demand but excluded the transport sector.

Several studies focus on power-to-heat in neighborhoods, thus coupling the power and the building sector (heat demand). Most of these studies include combined heat and power (CHP) systems that use natural gas [18-20,23], or gas boilers in houses [21], so they do not consider $100 \%$ renewable systems. Interesting findings are that decentralized energy systems lower peaks in energy demands for buildings [19,29], but transforming 
existing neighborhoods to energy-neutral on a yearly or monthly basis is not possible due to both economic as well as technological barriers [29]. Besides, Wouters et al. (2015) found lower costs designs for a heating network and microgrid operation with energy exchange between nodes [20]. Furthermore, Siraganyan et al. (2019) found that battery storage has no significant advantage on costs and $\mathrm{CO}_{2}$ reduction [21].

Some studies combine both power-to-heat and power-to-gas with a focus on providing heat and electricity in neighborhoods [23-25]. Gabrielli et al. [23] applied the concept of multi-energy systems, including both power-to-heat and power-to-gas, with a focus on minimizing total annual costs and total annual emission with a MILP. They included seasonal storage for hydrogen and short-term sensible heat storage on a yearly time horizon with hourly resolution. In a later publication, it was shown that power-to-hydrogen is important to achieve zero operational $\mathrm{CO}_{2}$ emissions in a neighborhood and maximize renewable self-consumption [24]. Murray et al. [25] have made an extensive model, including building data, building retrofit rates, included both hydrogen and thermal storage. Again optimization was done both on $\mathrm{CO}_{2}$ emissions and costs. Their results pointed out that both building retrofitting and renewable energy integration are necessary to meet the energy targets for buildings. This is one of the few publications on energy systems for neighborhoods that include seasonal heat storage, although it is modeled simplified with $1 \%$ heat loss per hour. The economic calculations did not include costs for grid reinforcement.

Lastly, two studies combined both the electricity, building (heat) and transport sectors [26,27]. The first is Maroufmashat et al. [26], who considered an energy network in Canada with four hubs, including a school, a food distribution center, a residential house complex and a hydrogen refueling station thus combining electricity, buildings (heat) and hydrogen in one concept. Another example of integrated energy and water system is the power-to-H3 concept that was introduced in our earlier publication [27]. This concept includes both power-to-heat as well as power-to-gas (hydrogen). For heat, seasonal storage is included as heat is stored at a temperature of $40-60{ }^{\circ} \mathrm{C}$ in a high-temperature aquifer thermal energy storage (HT-ATES) system during summer to fulfill heating demand during winter. However, the heat storage was modeled in a simplified way as the temperatures of both aquifers were kept constant during the runtime, so decreasing well temperatures during heat delivery were not considered.

Considering the literature on power-to-heat in neighborhoods, it is remarkable that seasonal heat storage is never really included, while other studies indicate it can be an economically favorable option for heat storage [30-32]. When heat storage is mentioned in energy system publications, it is modeled over a short period or with simplified loss factors. These papers then merely conclude that heat storage is only an option for short periods (up until a week). This conclusion is related to the specific heat storage solutions that are considered. For example, in the extensive review on power-to-heat technologies, modeling approaches and flexibility potentials by Bloess, Schill and Zerrahn [22], only hot water storage in tanks is assessed, and it is concluded that the capital costs are too high. Brown et al. [28], on the other hand, did look at a European level and conclude that both flexibility from electric cars, power-to-gas and long-term thermal energy storage can contribute to integrating intermittent renewables and reduce total system costs. Still, their analysis only includes hot water tanks. McKenna et al. (2019) [33] confirmed the lack of seasonal thermal storage systems as part of multi-energy systems and worked on the optimization of a tank thermal energy storage system. They found that high fractions of renewable heat supply require large seasonal storage capacities, which leads to $14 \%$ higher costs than a reference scenario with gas boilers. They conclude that a level of $60-80 \%$ renewable heat supply could be strived for in combination with demand-side measures. The potential of aquifer thermal energy storage, with lower investment costs than hot water tanks, appears to have not been explored before. Thus, in the current literature on power-to-heat and integrated energy systems for neighborhoods, seasonal thermal energy storage has been underexposed. 


\subsection{Focus of the Study}

The studies from the literature review show the potential benefit of integrated systems with various forms of system integration (i.e., sector-coupling). However, some aspects show potential for further enabling, or better performance, of system integration. We focus on the followings aspects of integrated energy and water systems, based on the caveats we found in the literature:

- Consider $100 \%$ renewable systems, so excluding fossil sources, such as natural gas;

- Taking into account multiple consumption sectors in a neighborhood (electricity, heating of buildings, mobility and water);

- Hydrogen can be used for more purposes than electricity only, as it can also be applied in both the transport sector and for buildings (heating and electricity purposes);

- Seasonal heat storage can contribute considerably to the large seasonal, temporal mismatch.

The novelty of our work is thus to consider integrated energy and water systems for existing neighborhoods based on 100\% renewable energy, taking into account multiple consumption sectors and different conversion and storage mechanisms (hydrogen and heat). It is yet to be identified to what extent these aspects contribute to a better performance of the energy- and water system in a neighborhood, both from a technical and economic perspective. This brings us to the central research question:

What is the impact of different modes of system integration on the local energy and water use, energy imports and exports, peaks in demand and supply and system costs for a neighborhood energy and water system?

In this study, we evaluate the potential of integrated energy systems by comparing four scenarios with different modes of system integration in an existing neighborhood. Thereby we take into account the aspects mentioned above that are unexplored in current literature. One of the main interests is to assess the impact of these different designs on the local use, imports and exports, peak demand and supply and (energy) system costs of the neighborhood. To answer the research question, a simulation model is developed to allow for systematic assessment of the different modes of system integration. The focus of this paper is on the energy system, while the contribution of water is done as a first-level approach of supply, demand and storage based on rainwater in the neighborhood.

The modeling methodology is outlined in Section 2. In Section 3, different modes of neighborhood system integration are described in four scenarios. The scenarios cover a range, starting from one energy carrier (all-electric) towards systems that allow for conversion between electricity, heat and hydrogen. However, this is not an exhaustive list of possibilities; other renewable energy systems are also possible. In Section 4, the results of the simulated scenarios are presented and analyzed, followed by a discussion in Section 5 . Finally, the conclusions are presented in Section 6.

\section{Modeling Methodology}

The model described here is an extended version of the power-to- $X$ model that was introduced together with the power-to-H3 concept in an earlier publication [27]. In this publication, the different calculations are described in more detail and extended with the energy demands and PV installations of households, electric mobility, electricity storage in batteries, fuel cells and numerical groundwater modeling for accurate modeling of an HT-ATES system. In Figure 1, an overview of the different model components and their interactions is shown. On the supply side, rainwater, surface water (for the heat pump), solar PV, wind turbines and the electricity grid are included in the model. Conversion and storage technologies comprise rain water storage and purification, electrolysis, hydrogen storage (tank and salt cavern), fuel cell, industrial heat pump, HT-ATES and a battery. We have chosen to only model central hydrogen storage as it is much cheaper than local (pressurized) hydrogen storage. Heat storage should be done locally, as heat transport over long distances leads to high losses and high costs for heat transport. The HT-ATES system includes a hot and a warm well to supply heat. It could also deliver cold when a third 
aquifer would be added to the system to create a triplet [34,35], but this is not covered in this paper. The neighborhood demands exist of water, mobility (either FCEV or BEV), heat (electric, district heating network or hydrogen) and electricity demand for appliances and lighting. Furthermore, the households partially supply themselves with electricity via solar $\mathrm{PV}$ on roofs. For the water demand, no specific design choices are made yet on how the water will be used. Some options are elaborated in the discussion. The specific technologies and component sizes that are combined in one system are chosen by the modeler.

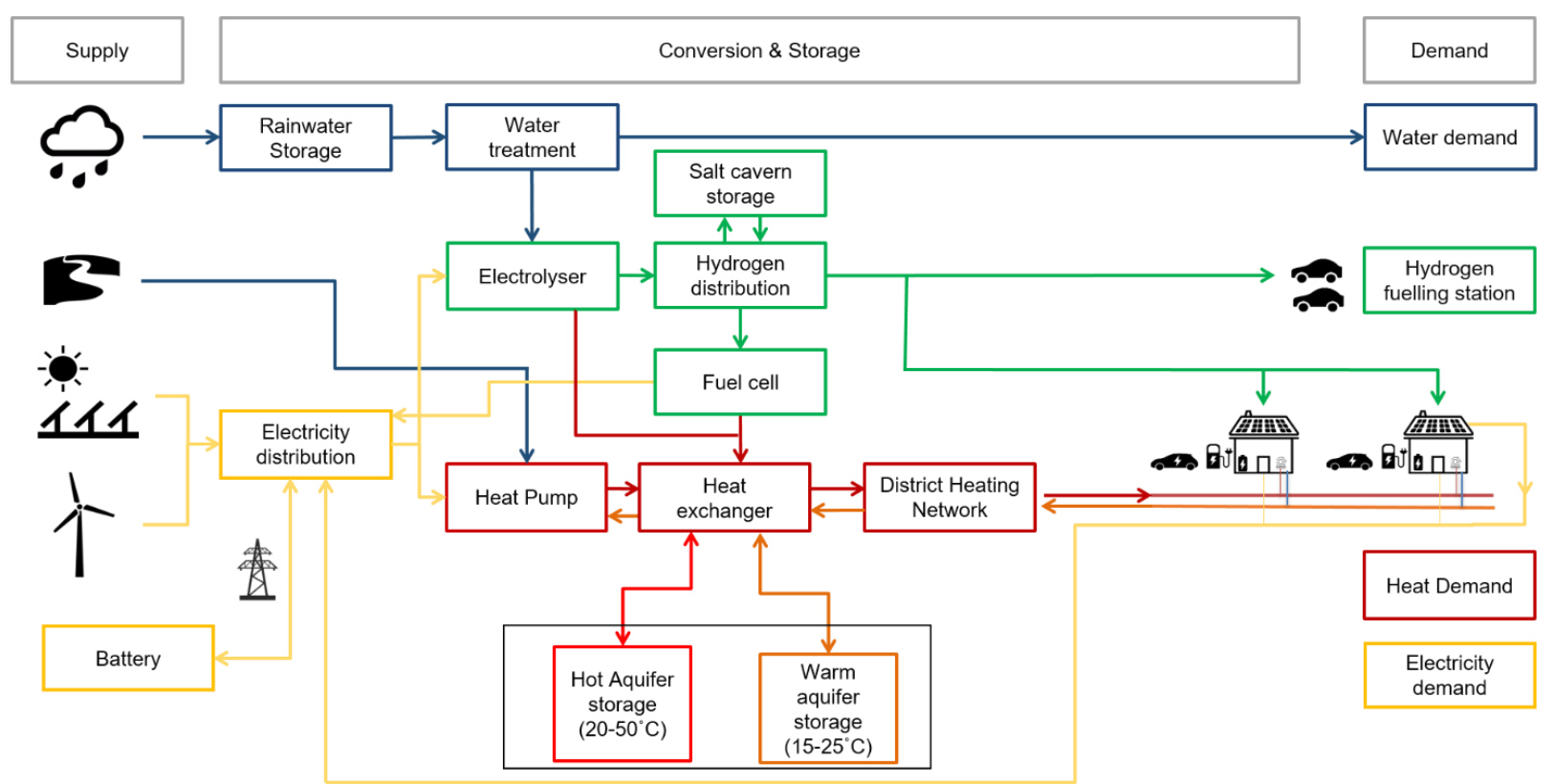

Figure 1. Schematic overview of the power-to-X model with all components and interactions. We distinguish a water (blue), electricity (yellow), hydrogen (green) and heat (red/orange) part in the system, with multiple connections between, i.e., water and hydrogen, water and heat, hydrogen and heat and electricity and heat. The demands are focused on the built environment, in which different houses with multiple demands are considered. Energy demands can be fulfilled locally by PV on roofs or a local PV or wind park, but remaining demands can be fulfilled by the grid as well. All model components shown in the figure are described in more detail in the supplementary information.

The model is created in Python and calculates the energy balance hourly for many years of varying weather data (to be chosen by the modeler). The first model step is to distribute the given (yearly) energy demands over time. Then, the supply of rainwater and renewable energy (wind/PV/surface water) are calculated based on geographical weather data. Next, the model tries to match energy supply and demand for every hour during the runtime by applying the different conversion and storage technologies. The different energy flows for supply, demand, conversion and storage result in an energy balance. Lastly, we perform an economic evaluation combining costs data of all technologies with the relevant parameters from the model run, such as the total volume of hydrogen produced and/or the amount of electricity that is exported or imported to/from the electricity grid.

Some important system elements for which a fixed efficiency or factor is used are summarized in Table 1. The numbers mentioned are targeted at a near-future scenario (2030) when we expect these types of systems to be economically feasible and mature. In the Supplementary Materials, the different model components are described in more detail. This includes system elements not mentioned in Table 1 because there is no fixed efficiency to mention (such as rainwater catchment or demand patterns for electricity and heat of households). 
Table 1. Overview of fixed efficiency parameters in the model. A more elaborate description per system element is included in the Supplementary Information.

\begin{tabular}{|c|c|}
\hline System Element & Energy Consumption/Efficiency \\
\hline Solar PV & $\begin{array}{c}\text { Hourly calculation within the model based on HOMER formulas [36], with irradiation and temperature as inputs } \\
\text { fixed } 10 \% \text { loss factor (shadow, dust, waste, cables) } \\
\text { fixed linear derating factor to } 81 \% \text { of original efficiency over } 25 \text { years }\end{array}$ \\
\hline Electrolyzer & $78.8 \%$ efficiency (HHV, $50 \mathrm{kWh} / \mathrm{kg}$, on AC) [37] at $90 \%$ load \\
\hline Industrial heat pump & $C O P_{H P}=0.0028\left(T_{H P, \text { cond }}-T_{H P, \text { evap }}\right)^{2}-0.3276\left(T_{H P, \text { cond }}-T_{H P, \text { evap }}\right)+13.021[38]$ \\
\hline House heat pump & $\begin{array}{l}\text { Air sourced: } C O P_{A S H P}=6.08-0.09 \cdot\left(T_{\text {out }}-T_{\text {in }}\right)+0.0005\left(T_{\text {out }}-T_{\text {in }}\right)^{2}[39] \\
\text { Water sourced: } C O P_{\text {WSHP }}=9.97-0.02 \cdot\left(T_{\text {out }}-T_{\text {in }}\right)+0.0012\left(T_{\text {out }}-T_{\text {in }}\right)^{2}[39]\end{array}$ \\
\hline $\mathrm{H}_{2}$ boiler & $98 \%$ efficiency (HHV) \\
\hline Heat exchanger & Fixed heat loss of $1.5^{\circ} \mathrm{C}$ \\
\hline fuel cell & $60 \%$ efficiency-(HHV) \\
\hline Rainwater storage & $70 \%$ recovery efficiency [40] \\
\hline HT ATES & $\begin{array}{c}\text { Input temperature warm well } 50^{\circ} \mathrm{C} \\
\text { Hydrological model (see Supplementary Materials Section } 33 \text { ) to determine the efficiency }\end{array}$ \\
\hline District heating network (DHN) & $\begin{array}{l}2 \% \text { energy use for pumping, heat loss determined per hour (see Supplementary Materials Section } 4.2) \\
95 \% \text { one-way efficiency }[10,41]\end{array}$ \\
\hline Battery & $\begin{array}{l}25 \%(4 \mathrm{C}) \text { charge/discharge rate }[41] \\
\text { max } 90 \% \text { depth of discharge (DOD) }\end{array}$ \\
\hline Electricity grid & $98 \% \mathrm{AC} / \mathrm{DC}$ conversion \\
\hline $\mathrm{BEV}$ charging & $90.7 \%$ charging efficiency [42] \\
\hline
\end{tabular}

The economic parameters, such as the investment costs (capital expense or CAPEX), operation and maintenance (OM) and lifetime, are presented in Table 2.

\subsection{Rule-Based Scheduling Strategy}

The size of system components is not set by an algorithm within the model but is defined by the user. For the calculations and scenarios in this paper, the following scheduling strategy is in place to decide how supply and demand are connected within the model. If certain system components are not part of a scenario, they are skipped in the scheduling strategy.

Electricity supply from PV on houses is first used within the house itself (for appliances, lighting, heat pump and/or BEV), then it is evaluated whether an excess of PV electricity in some houses (i.e., a terraced house) could be used to fulfill the demand in others (i.e., in a multi-apartment building with a shared roof). The next evaluation is whether the industrial heat pump (coupled with the HT-ATES) could take up electricity, followed by the electrolyzer. The heat pump is prioritized in the scheduling strategy because it needs to produce enough heat for the heat storage system to provide heat in winter. There is a cap on the amount of heat stored based on the yearly heat demand plus a loss factor, explained in Supplementary Materials Section 3.3. Hydrogen can also be imported from outside the system and thus has less priority. If after the houses, industrial heat pump and electrolyzer, any electricity are left, it is stored in the (collective) battery, and when this is not possible, the electricity is exported to the grid.

The electricity supply from local RES production (PV park or wind turbines) is first used by the industrial heat pump coupled to the heat storage system, followed by the electrolyzer. For this part of the supply, the collective installations are prioritized in the scheduling strategy because it is assumed that those installations will be placed close to the local RES production and can, therefore, reduce peaks in that part of the grid. Subsequently, it is evaluated whether the households still have an electricity need, followed by storage in the battery. Lastly, any surplus electricity is exported to the grid.

To fulfill an electricity demand, the prioritization is reversed. Hence, a household electricity demand is first fulfilled by their own PV system, followed by local RES production, then the battery and the fuel cell. Finally, when the electricity demand is not yet fulfilled, electricity is imported from the grid. The modeler can choose if the fuel cell functions as a peak shaver (only when the grid has not enough capacity) or more as a baseload, always fulfilling any leftover electricity needs up until its full capacity. The heat from the electrolyzer and fuel cell is only reused when a district heating network (DHN) is in place. In that case, the heat is first used to fulfill any direct heat demand. Any heat that cannot 
be used directly is stored in the HT-ATES system. In system designs without a DHN or HT-ATES, the heat is denoted as heat loss.

Table 2. Economic component parameters used in the model.

\begin{tabular}{|c|c|c|c|}
\hline & CAPEX & Lifetime & $\begin{array}{l}\text { OM Cost (\% of Investment Cost } \\
\text { Unless Stated Otherwise) }\end{array}$ \\
\hline \multicolumn{4}{|l|}{ Neighborhood systems } \\
\hline PV panels (park) & $600 € / \mathrm{kWp}[43-45]$ & 25 & $1.5 \%$ \\
\hline Battery storage & $300.000 € / \mathrm{MWh}[10,41]^{\mathrm{a}}$ & 12 (4000 cycles) $[10]$ & $1 \%$ \\
\hline Electrolyzer & $500 € / \mathrm{kW}[42,46,47]$ & $20[42]$ & $2 \%[42]$ \\
\hline Fuel cell (stationary) & $500 € / \mathrm{kW}^{\mathrm{b}}[37,46,48]$ & $15[48,49]$ & $2 \%$ \\
\hline Heat pump & $400 € / \mathrm{kW}_{\mathrm{th}}{ }^{c}[48,50,51]$ & $20[48]$ & $1 \%[48]$ \\
\hline Heat storage system & $0.1 € / \mathrm{kWh}_{\text {th }}$ & $40[27]$ & $1.5 \%[27]$ \\
\hline District heating network $^{d}$ & $6000 € /$ house [52] & 40 & $2 \%[53]$ \\
\hline Grid reinforcement ${ }^{\mathrm{e}}$ & $862 € / \mathrm{kW}[54]$ & 40 & $1 \%$ \\
\hline \multicolumn{4}{|l|}{ Household systems } \\
\hline PV panels (roof) & $870 € / \mathrm{kWp}[48]$ & 25 & $1.2 \%[48]$ \\
\hline Air-sourced heat pump ${ }^{f}$ & $6000 € /$ house $[54]$ & 15 & $2 \%$ \\
\hline Booster heat pump $\mathrm{g}$ & $1000 € /$ house [55] & 15 & $2 \%$ \\
\hline Hybrid heat pump, including boiler & $4300 € /$ house $[54]$ & 15 & $2 \%$ \\
\hline Adjustments gas network for hydrogen + new gas meter & $373 € /$ house $[56]$ & 40 & $274 € / y /$ house $^{\mathrm{h}}[57,58]$ \\
\hline Electricity grid costs & & & $308 € / \mathrm{y} /$ house $^{\mathrm{i}}[57]$ \\
\hline Renovation costs-D- $C^{j}$ (13\% energy savings) & $2940 / 4680 € /$ house $[54]$ & 40 & - \\
\hline Apartment/terraced & 2940/4680 €/ house [54] & 40 & - \\
\hline \multicolumn{4}{|l|}{ Renovation costs-D- $\mathrm{B}^{\mathrm{j}}$} \\
\hline (20\% energy savings) & $4560 / 9600 € /$ house $[54]$ & 40 & - \\
\hline \multirow{2}{*}{\multicolumn{4}{|c|}{$\begin{array}{c}\text { Apartment / terraced } \\
\text { Renovation costs-D-A }\end{array}$}} \\
\hline & & & \\
\hline ( $34 \%$ energy savings) & $7320 / 19,200 € /$ house $[54]$ & 40 & - \\
\hline Apartment/terraced & & & \\
\hline
\end{tabular}

a Projected battery costs by IRENA for 2030 are $150 € / \mathrm{kWh}$, but it is unclear if this includes power conversion and balance of plant. Therefore, the IRENA value was used as capital costs for energy capacity, while on top of that, data from Mongird et al. [41] were used to make sure to include power conversion, the balance of plant and construction and commissioning. As Mongird et al. only give values for 2025 , we have used the lower range values to estimate the costs for 2030 . $^{\mathbf{b}}$ sources range from $425-1500 € / \mathrm{kW}$ for stationary systems, but fuel cell systems for cars have much lower price expectations (250-300 $€ / \mathrm{kW}$ [59]). We expect that developments in the transport sector will also reduce the costs for stationary systems and have used lower range value here. ${ }^{c}$ The cost for the heat pump is based on multiple sources and supplier data. The heat pump capacity in $\mathrm{kW}_{\text {th }}$ is calculated by multiplying the electric capacity (in $\mathrm{kW}_{\mathrm{el}}$ ) with the average COP of the heat pump over a run time. The costs include installation costs (which are approximately $50 \%$ of the investment cost). ${ }^{\mathrm{d}}$ Costs for the DNH itself plus household installations for an outer city area. The OM costs mentioned in the source are actually $1 \%$, but in this paper, we look specifically at a low-temperature DHN with insulated pipes that probably needs more maintenance, and therefore, we have multiplied this value by a factor of two. ${ }^{\mathrm{e}}$ This includes costs for the low voltage grid (=distribution grid) up until the transformer station to the high voltage grid (=transmission grid), but no costs for the transmission grid itself because this study focuses on local optimization and makes no concrete assumptions for the changes in the transmission grid. ${ }^{\mathrm{f}}$ Currently these costs are around $8000 € /$ house, but we expect a cost decrease of $25 \%$ due to learning effects by upscaling in production. ${ }^{g}$ Included a $50 \%$ cost reduction to extrapolate to 2030 because, in 2020, it is still relatively new technology, so a large economy of scale effect is expected. ${ }^{\mathrm{h}}$ These costs are based on the current fixed yearly costs for gas consumers, about $68+186=254 € / y[57]+$ extra costs concerning the expected changes in the inspection regime when switching to a hydrogen of $20 € / y$ [56]. ${ }^{i}$ Fixed costs for an electricity grid connection for consumers per year. ${ }^{j}$ Costs for insulation are based on gas demand related to energy labels for apartments and terraced houses in the Netherlands (2018) [60]. The gas demand is converted to space heating energy demand through a correction for cooking gas, domestic hot water and the average efficiency of the boiler [61] (p. 52/53) and finally the\% of gas savings when renovating to a higher energy label (Dutch terminology for savings on building energy use). An A-label house is comparable to what many European countries would classify a nearly zero energy building with an energy consumption between 45 and $70 \mathrm{kWh} / \mathrm{m}^{2}$ [62]. The costs for retrofitting are calculated based on the average surface area of the house [54] (p. 71). Insulation requires no maintenance, so no OM percentage is included.

If a heat pump is installed and needs the energy to heat up water from the hot well of the heat storage system during winter (see Supplementary Materials Section 3.3), it is first evaluated whether it could be fulfilled by the local RES production, followed by a possible surplus of the PV systems on the households. If energy demand is still not fulfilled, it is evaluated whether electricity is still stored in the battery or if electricity can be produced by the fuel cell. Any leftover demand is fulfilled by import from the electricity grid.

Hydrogen production is always exported to the hydrogen gas grid, and hydrogen supply is fulfilled by the hydrogen gas grid. If a DHN is in place, heat demand is fulfilled first with heat from the electrolyzer or fuel cell (if available), then by direct production from the heat pump (if available) and otherwise from the HT-ATES. 


\subsection{Economic Calculations}

Costs are defined here as system costs, represented as the costs per household per year that include costs for electricity, heat and mobility. In the cost calculations, the levelized costs per system component $(L C)$ are determined according to Equation (1):

$$
L C_{i}=\alpha \cdot C A P E X_{i}+O M_{i}+\sum_{0}^{8760} E \operatorname{cost}_{i}
$$

here $L C_{i}$ represents the annual levelized costs for a certain system component in ( $€$ /year). Here the $\operatorname{CAPEX}_{i}(€)$ covers the capital expenditures for a particular system component $I$ (i.e., the PV panels, the electrolyzer, compressor or storage tank) and $O M_{i}(€ /$ year) represent the operational expenditures for a particular system component. $E \cos _{i}(€ /$ year $)$ are the electricity costs for a system component $i$. The capital recovery factor $(\alpha$, no unit) in Equation (2) represents a fraction of the total CAPEX cost. In this way, a constant yearly value of depreciation is calculated based on the lifetime of the system component and the discount rate.

$$
\alpha=\frac{r}{1-(1+r)^{-L_{i}}}
$$

With $r$ the discount rate (as a fraction of 1 ) and $L_{i}$ (year), the lifetime of a particular system component $i$.

The costs per household per year (HC) are then calculated according to Equation (3) by dividing the sum of the yearly cost of all system components by the number of households in the neighborhood:

$$
H C=\frac{\sum_{i=1}^{n} L C_{i}}{N_{\text {households }}}
$$

A complete overview of all economic parameters per system component and some general economic parameters are given in Tables 2 and 3. All costs mentioned here are for the near future (2030). We have excluded investment costs in vehicles (BEV/FCEV) as we expect these costs to become similar to fossil-fuel cars [37] and will be similar for

\begin{tabular}{|c|c|}
\hline Discount Rate ${ }^{a}$ & $3 \%[63]$ \\
\hline Grid electricity costs $2030(100 \% \text { renewable })^{b}$ & $115(70-145) € / M W h[64]$ \\
\hline Feed-in tariff ${ }^{c}$ & $57 € / \mathrm{MWh}[65]$ \\
\hline Extra infrastructure for peak capacity in all-electric scenario ${ }^{d}$ & All electric: $5 € /$ MWh [64] \\
\hline \multirow{4}{*}{ Hydrogen import costs ${ }^{e}$} & Production: $2.5 € / \mathrm{kg}(1.5-3.5 € / \mathrm{kg})[37,47,58,66]$ \\
\hline & Storage: $0.2 € / \mathrm{kg}[67]$ \\
\hline & Transport: $0.39 € / \mathrm{kg}$ for $3000 \mathrm{~km}(0.09-0.17 € / \mathrm{kg}$ for $1000 \mathrm{~km})$ [66] \\
\hline & Total: $3.09 € / \mathrm{kg}(1.8-4.55 € / \mathrm{kg})$ \\
\hline
\end{tabular}
all scenarios.

Table 3. Other relevant economic parameters.

${ }^{a}$ We assume one discount rate for the total system, while in reality, the discount rate will differ depending on if the investment is done by a household (i.e., household PV system) or a company (i.e., a district heating network). Here we look at the societal costs, and therefore, we have used a social discount rate. ${ }^{\mathrm{b}}$ The assumption made here is that the electricity used in the system is climate neutral. It includes costs for production, transport, distribution and extra grid cost (due to more complex balancing in a $100 \%$ renewable energy system). The range chosen by PBL is 70-145 $€$ /MWh for 2030 , with an average of $115 € /$ MWh for smaller users ( $<50 \mathrm{MWh}$ /year). ${ }^{\mathrm{c}}$ Cuts on feed-in tariffs have occurred globally for utility-scale systems [9], and with still decreasing costs for PV, feed-in tariffs for individual home power systems are being reduced as well, at least in western countries. We expect a phase-out of the feed-in tariff, and therefore, we have chosen a feed-in tariff equivalent to the expected market price for renewable electricity in 2030 [65]. ${ }^{\mathrm{d}}$ Due to more complex system balancing in an all-electric system, extra overhead costs (for balancing the grid) are estimated at $5 € / \mathrm{MWh}$ [64]. ${ }^{\text {e }}$ The hydrogen storage costs are a calculation for ten storage cycles (so closer to seasonal storage than daily storage), based on the cost numbers given in Roobeek et al. (2020) [67]. We do not know exactly where the imported hydrogen will come from, but assuming a distance of $3000 \mathrm{~km}$ allows for import by pipeline from North Africa, Ukraine [47] or southern Europe, regions with favorable climates for wind and solar power and low hydrogen production costs.

\section{Neighborhood Scenarios}

The neighborhood presented here is based on an actual neighborhood in Nieuwegein, the Netherlands, but modified for generalization. The amount of houses (2000) corresponds to an average European neighborhood as defined in earlier research into a transport and 
energy system for a neighborhood [15] and is close to an average Dutch neighborhood as well [68]. The neighborhood has an electricity infrastructure, water and wastewater distribution network and a natural gas network. Because $95 \%$ of the Dutch households are heated by natural gas [69], we assume that a district heating network is not yet in place in this neighborhood, but the density of the housing stock is high enough to install one. We only consider the energy use of houses in the neighborhood and not nonresidential energy use. Furthermore, it is assumed that every household owns a car.

The reference situation of the neighborhood is shown in Figure 2. The buildings were build during 1975-1991 with 50\% apartment buildings and 50\% terraced houses. The annual gas demand is calculated with $31.65 \mathrm{MJ} / \mathrm{m}^{3}$ natural gas, which is the average value for the low-caloric gas used in the Netherlands. For an apartment, the annual gas demand is $1020 \mathrm{~m}^{3}$ (9 GWh for 1000 apartments) and $1350 \mathrm{~m}^{3}$ (11.9 GWh for 1000 terraced houses) for a terraced house, including space heating, tap water and cooking [70]. We have used data on average gas use to determine the peak in gas demand [71] and used a boiler efficiency of 1.0 based on the house types [61]. For 2000 houses, this results in average hourly peak demand for gas of $980 \mathrm{~m}^{3}$ or $9.8 \mathrm{MW}_{\mathrm{p} \text {,-gas }}$ with an average peak demand per

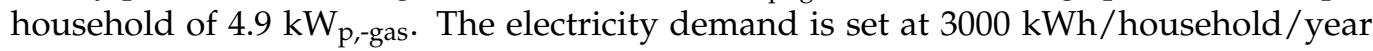
for a terraced home and $2400 \mathrm{kWh}$ for an apartment, based on various data on Dutch house types and building years [57,70]. Average electricity demand patterns were used to divide the electricity demand over the year (see Supplementary Materials Section 5.3.1 and [71]). By using these patterns, the average peak demand for electricity per household is $0.66 \mathrm{~kW}_{\text {p-elec }}$.

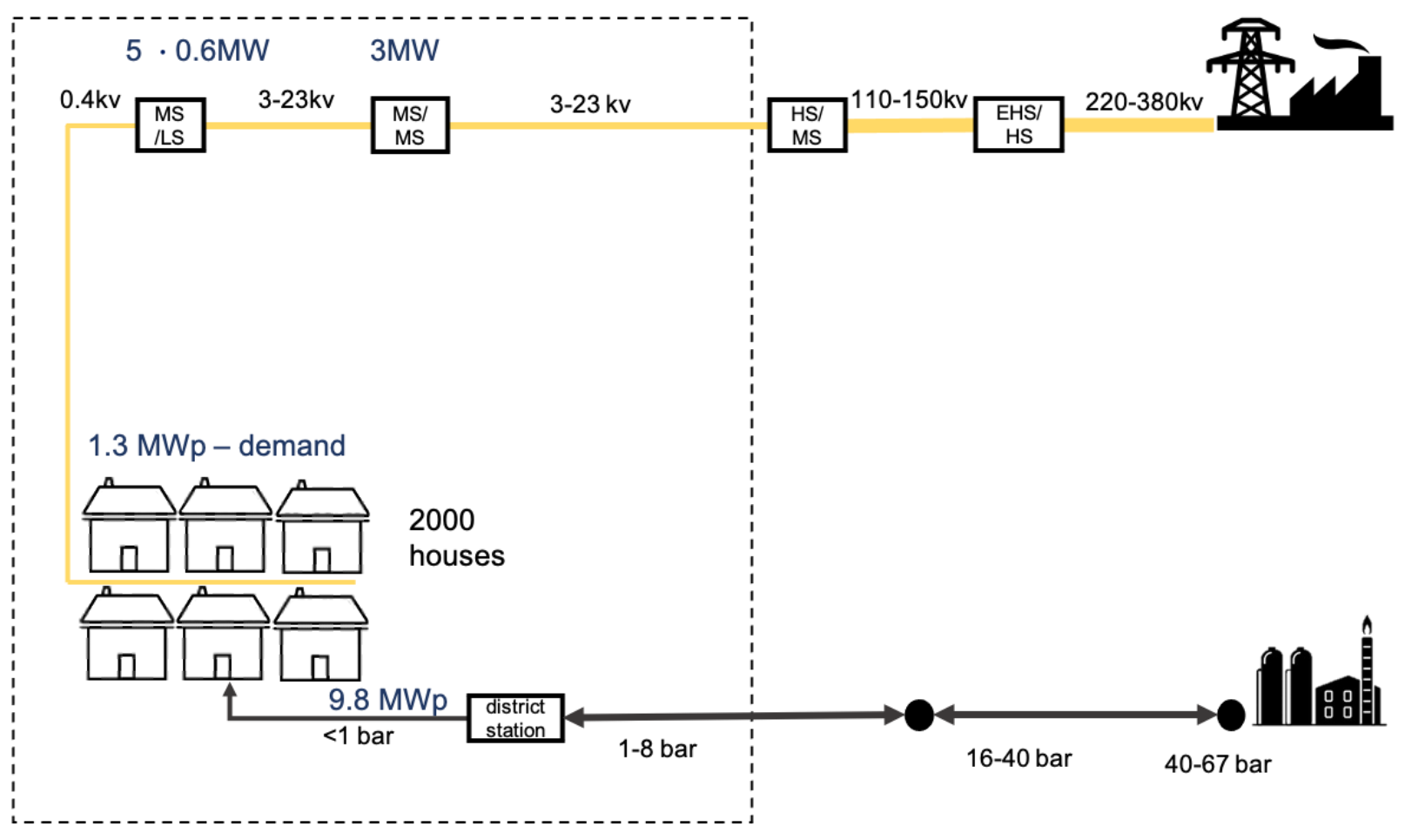

Figure 2. Schematic overview of the reference scenario without local renewable production, conversion and storage and with a gas grid for heating demand. This reference scenario has non-renewable electricity and natural gas as their energy sources. The energy demands are based on an existing neighborhood with 50\% terraced houses and 50\% apartments without solar PV. The houses have not yet been retrofitted and/or insulated.

The average peak capacity that the grid operators use for existing neighborhoods is $1.2 \mathrm{~kW}$ per household $[54,72]$. This means that when considering the simultaneity factor for a neighborhood of more than 1000 households, the average peak capacity available per household in a low-medium voltage grid station is $1.2 \mathrm{~kW}$. We assume that some extra 
capacity is available in a substation that connects the low voltage grid to the medium voltage grid. Therefore, we have assumed that for a neighborhood of 2000 households, $3 \mathrm{MW}$ of capacity is available at the station $(1.5 \mathrm{~kW}$ average peak capacity per household). The electricity peak demand that we calculated for the reference situation $\left(0.66 \mathrm{~kW}_{\mathrm{p} \text {-elec }}\right.$. of the neighborhood is almost a factor two lower than the value used by the grid operators. A possible explanation is using hourly (average) data, which means that peaks that occur on a shorter time interval within are flattened out. This flattening effect is more apparent for the electricity demand patterns than for gas, as electrical appliances have a more intermittent use pattern (water cooker, vacuum cleaner) than a gas boiler. It is important to be aware of this in the further analysis as the peaks in electricity demand and supply will probably be a conservative estimation.

With the reference situation of the neighborhood (Figure 2) as a starting point, we created four scenarios based on 100\% renewable energy sources. Renewable energy is supplied by own decentralized PV on roofs, a small PV park, or via the electricity grid. We have summarized the most important data about the neighborhood in Table 4 . In the reference situation, the houses have energy label D, but retrofitting to a higher energy label is possible to reduce the energy demand for space heating, as specified in Table 4. Energy demand for domestic hot water is set at $920 \mathrm{kWh} /$ person/year $(=3.3 \mathrm{GJ})$, which is based on different building types and domestic hot water demands [61]. Because electric cooking is not a common practice yet in the Netherlands, we included $175 \mathrm{kWh} /$ household/year for electric cooking on top of the average electricity demand for appliances and lighting [73]. All roofs are equipped with solar panels of $400 \mathrm{Wp}, 12$ panels on a terraced home (S-W, $45^{\circ}$ inclination) and two panels ( $S, 36^{\circ}$ inclination) per household on an apartment building. Additionally, there is a PV park near the neighborhood of $2 \mathrm{MWp}$, again with $400 \mathrm{Wp}$ panels $\left(S, 15^{\circ}\right.$ inclination). Wind turbines are not included in the scenarios as wind turbines are not likely to be placed in or very close to existing neighborhoods. For mobility, we assume that $70 \%$ of the houses have an electric car and 30\% a hydrogen car. A BEV or FCEV drives $13,000 \mathrm{~km}$ per year [74] (average NL). With an energy consumption of $20 \mathrm{kWh} / 100 \mathrm{~km}$, the energy consumption is $2600 \mathrm{kWh} / \mathrm{BEV} /$ year [75-77], or $110 \mathrm{~kg}$ of hydrogen for an FCEV with $60 \%$ fuel cell efficiency. For the BEV, we assume they charge $60 \%$ of the time at home.

Table 4. Energy demands and supply in the neighborhood.

\begin{tabular}{|c|c|c|c|}
\hline & Terraced & Apartment & Total \\
\hline Number of houses & 1000 & 1000 & 2000 \\
\hline Surface area per house & $120 \mathrm{~m}^{2}$ & $60 \mathrm{~m}^{2}$ & - \\
\hline People per household & 2.4 & 2 & - \\
\hline Solar panels on the roof & $4.8 \mathrm{kWp}$ & $0.8 \mathrm{kWp}$ (shared roof) & $5.6 \mathrm{MWp}$ roof $\mathrm{PV}$ \\
\hline Local PV park & - & 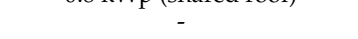 & $2 \mathrm{MWp}$ \\
\hline Energy demand domestic hot water & 2200 kWh/year & 1840 kWh/year & 4 GWh/year \\
\hline \multirow{4}{*}{ Space heat demand ${ }^{a}$} & A-5590 kWh/year & A- $4045 \mathrm{kWh} /$ year & A-9.6 GWh/year \\
\hline & $\mathrm{B}-6770 \mathrm{kWh} /$ year & $\mathrm{B}-4900 \mathrm{kWh} /$ year & B-11.7 GWh/year \\
\hline & $\mathrm{C}-7365 \mathrm{kWh} /$ year & $\mathrm{C}-5330 \mathrm{kWh} /$ year & $\mathrm{C}-12.7 \mathrm{GWh} /$ year \\
\hline & $\mathrm{D} \_8465 \mathrm{kWh} /$ year & $\mathrm{D}-6130 \mathrm{kWh} /$ year & D-14.6 GWh/year \\
\hline $\begin{array}{l}\text { Electricity demand } \\
\text { (including electric cooking) }\end{array}$ & $\begin{array}{c}3000 \mathrm{kWh} / \text { year } \\
+175 \mathrm{kWh} / \text { year cooking }\end{array}$ & $\begin{array}{c}2400 \mathrm{kWh} / \text { year } \\
+175 \mathrm{kWh} / \text { year cooking }\end{array}$ & $5.4 \mathrm{GWh} /$ year \\
\hline Mobility & $\begin{array}{c}\text { BEV-2600 kWh/year } \\
\text { FCEV-110 kg/year } \\
\text { (4.333 kWh/year-HHV based })\end{array}$ & $\begin{array}{c}\text { BEV—-2600 kWh/year } \\
\text { FCEV-110 kg/year } \\
(4.333 \mathrm{kWh} / \text { year-HHV based })\end{array}$ & $\begin{array}{c}\text { BEV: FCEV = 70/30: } \\
\text { Electric cars-3.6 GWh/year (of, which } \\
2.2 \mathrm{GWh} / \text { year at home charging) } \\
\text { Hydrogen cars-66 tons } \mathrm{H}_{2}-2.6 \mathrm{GWh} / \text { year }\end{array}$ \\
\hline
\end{tabular}

a The letters refer to a specific energy label (A-D). An A-label house is comparable to what many European countries would classify a nearly zero energy building with an energy consumption between 45 and $70 \mathrm{kWh} / \mathrm{m}^{2}$ [62]. The space heat demand is based on a gas demand for a terraced house or apartment build between 1975 and 1991 in the Netherlands with energy label D [60]. From this number, the energy demand for space heating is derived with a correction for cooking gas, and domestic hot water and the average boiler efficiency [61] and then the energy demand is reduced by a certain percentage [54] related to insulating a house to obtain a higher energy label.

For weather data, such as irradiation, wind speed, precipitation and temperature, we consider a northwest European climate. Data from the central weather station De Bilt of the Dutch Meteorological Institute (KNMI) is used [78]. Simulation time is five years (2010-2015) to consider yearly variation in weather conditions. This period is representative in terms of average temperature (with both warmer and colder years than average). A representative point for a peak in heat demand by households was the especially cold 
period in February 2012 when the temperature decreased to $-18{ }^{\circ} \mathrm{C}$. There is enough variation between dry, wet and normal years for precipitation. The period was sunnier than the long-term average, leading to a slight overestimation of the produced solar energy. However, every year since 1999 has been sunnier than the long-term average, which points in the direction of a trend to a sunnier climate in the Netherlands for the future and as we look at the year 2030, we do think the irradiation data are representative.

For surface water temperatures, 10-min data from Rijkswaterstaat [79] are available for the Lekkanaal (in Nieuwegein) and averaged to produce hourly values. If data are missing, data from the last hour are repeatedly used until data appear again. In general, this period is no longer than a couple of 10-min time intervals.

\subsection{Design Choices}

The focus of this paper is to analyze different designs with varying modes of system integration within a neighborhood, which leads to a different choice and sizing of conversion and storage technologies. We strive to use as much energy locally as possible while there still is a connection to the electricity and/or gas grid. We have chosen four scenarios that represent different modes of system integration, yet other scenarios would be possible as well. The designs presented here are either a well-known option (all-electric) or designs, including techniques that we have identified as gaps in the literature (see Section 1.3) and/or integrate more different energy carriers. A high-temperature district heating network $\left(>70{ }^{\circ} \mathrm{C}\right)$ is not considered because it is not yet in place and high-temperature heat sources are not locally available. Low-temperature ATES systems $\left(15-20^{\circ} \mathrm{C}\right)$ are not considered here as well, as these houses have no cold demand. For thermal heat storage, we have chosen an HT-ATES system. We did not include hot water tank storage, which has been done in other literature $[22,25,28]$, because tanks do not provide enough storage volume for seasonal storage. Pit thermal energy storage could have been another option, but free space is needed to install the structure in the subsurface, which is not easily available in existing neighborhoods. If the PV park is installed close to the neighborhood $(<2 \mathrm{~km}$, to avoid heat losses) on a free space, such as a meadow, it could be possible to install a pit thermal energy storage system under the PV park. With an HT-ATES system, the necessary above-ground space to drill, install and operate the wells is relatively small, while the system has a sufficient size to function as a seasonal energy storage system, and the investment costs are relatively low.

A completely hydrogen-based system for space heating and tap water or fuel cells in houses are other possible options to include in the design, but for now, we have chosen to have one scenario with partly hydrogen-based heating demand. Thus, the scenarios chosen are mainly an illustration of a line of reasoning and do not show results for all possible $100 \%$ renewable energy system designs.

Another aspect is that the storage and conversion of renewable energy outside the neighborhood will not be modeled (outside highlighted area in Figures 3-6). These storage mechanisms are larger than necessary for a neighborhood and generally used by a whole region or country. They are placed at central locations outside the neighborhood and are, therefore, outside the scope of this research. We do not know yet how storage and conversion in the system on an (inter)national scale will be designed. Instead of modeling the (inter)national energy system with many assumptions and high uncertainties, we have chosen to represent the possible options by including a range of prices for the import of electricity and/or hydrogen. In this way, we will be able to get insights on when system integration on a local level can be beneficial concerning the price developments in the overall energy system. We do, however, assume a $100 \%$ renewable-based energy system, which does also imply that only green hydrogen is imported. 


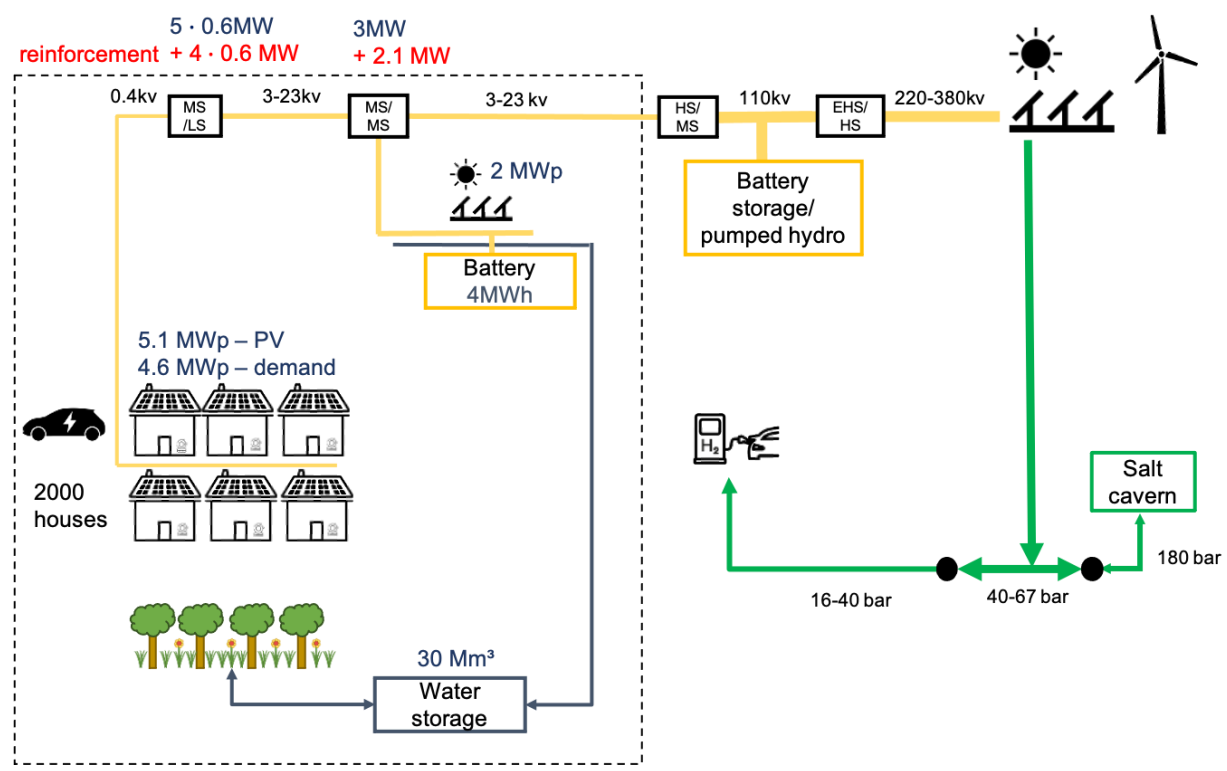

Figure 3. Schematic overview of the all-electric scenario with the respective supply and storage capacities. This scenario is based on $100 \%$ renewable electricity, either from local PV production on roofs or the local solar park or imported from large-scale renewable capacity via the electricity grid. The system boundary is shown with a dotted line. Outside of the system boundary, we do not model the electricity production, conversion and storage. However, we assume both electricity storage (in the form of batteries or pumped hydro) and hydrogen storage (via electrolysis) in salt caverns are included in the larger energy system. Because of the local PV production and electricity demands for, i.e., heat pumps, the original grid capacity of $3 \mathrm{MW}$ is not sufficient anymore for this neighborhood. The red numbers with the plus sign represent the grid reinforcement that is necessary for this scenario. Inverters are not shown in this picture but are necessary for the transformation of DC to AC electricity.

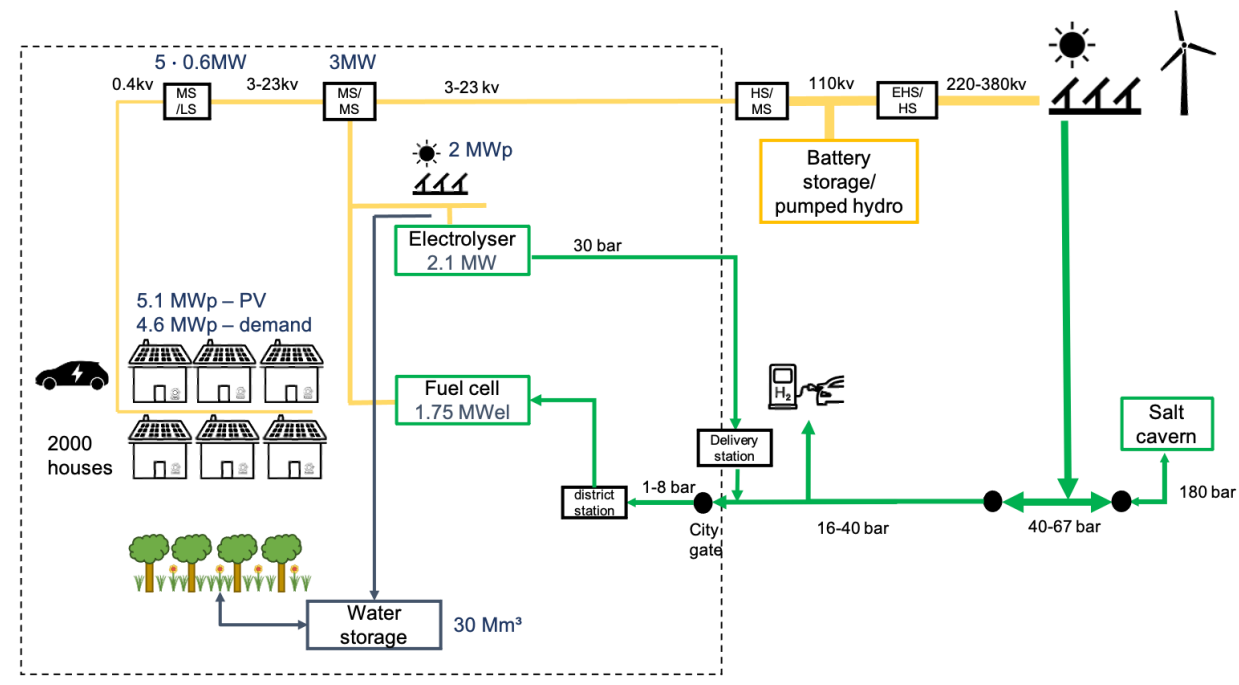

Figure 4. Schematic overview of the all-electric $\mathrm{H}_{2}$ scenario that includes both an electrolyzer and fuel cell for local hydrogen production and uses while preventing grid reinforcement. The electricity supply by PV and electricity demand is the same as in the all-electric scenario (Figure 3), but instead of grid reinforcement, an electrolyzer (2.1 $\left.\mathrm{MW}_{\mathrm{el}}\right)$ shaves peaks in electricity export. On the other hand, the fuel cell has a sufficient capacity $\left(1.75 \mathrm{MW}_{\mathrm{el}}\right)$ to shave demand peaks, thereby avoiding grid reinforcement. The fuel cell is utilized as a baseload installation in the system. The fuel cell would have a very low usage otherwise $(0.3 \%$ of the year). This scenario will import more hydrogen than electricity, so the effect of large amounts of hydrogen import can be assessed. 


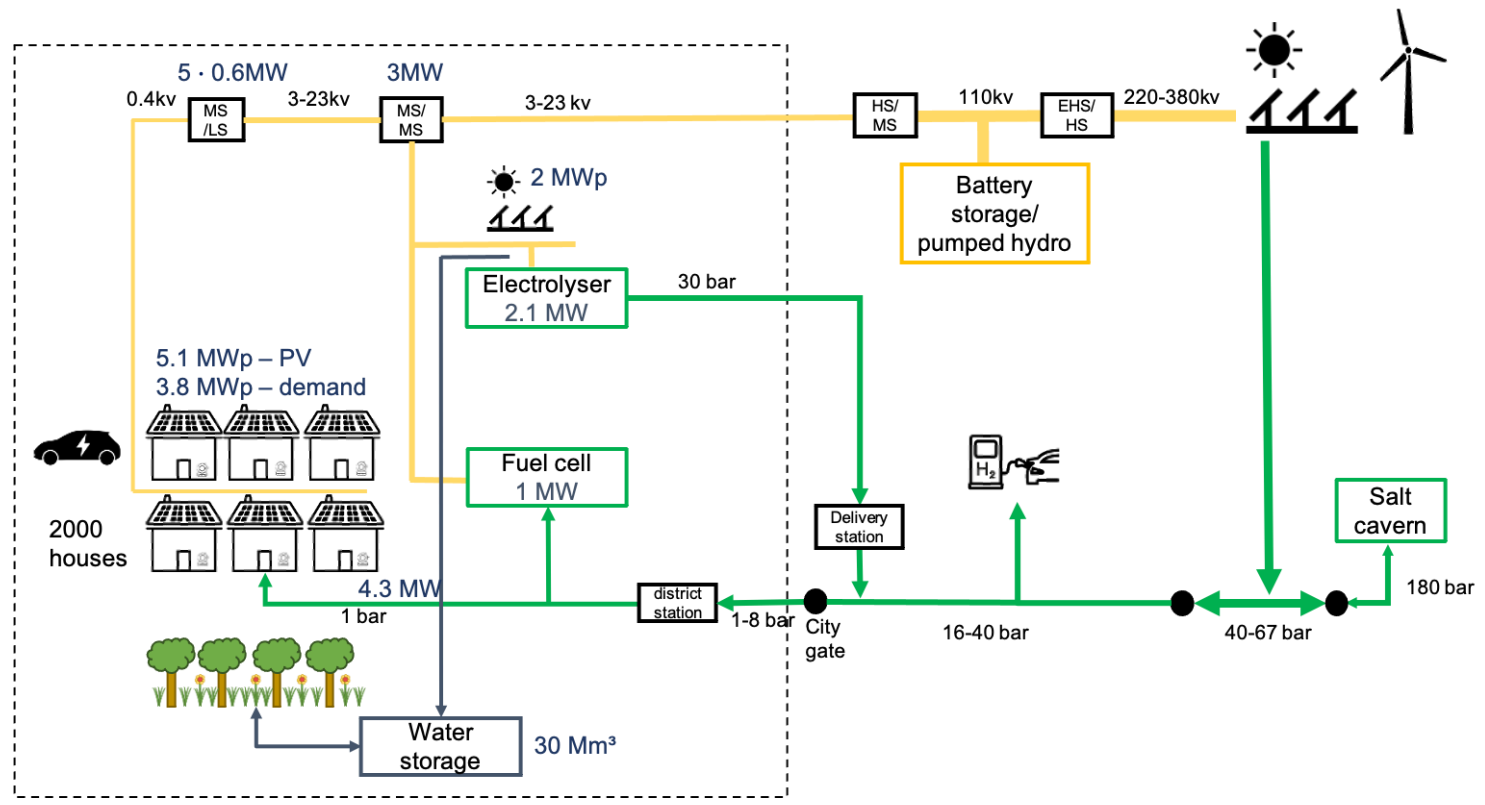

Figure 5. Schematic overview of the $\mathrm{H}_{2}$ hybrid scenario with power-to-hydrogen and using hydrogen for household heating demand. The electrolyzer (2.1 $\left.\mathrm{MW}_{\mathrm{el}}\right)$ is utilized for peak shaving on the supply side (PV on roofs and the local PV park). The houses are retrofitted to a lesser extend (label C) than in the all-electric scenarios (see Table 4), which results in higher heating demands. In this scenario, we have chosen to fulfill the heating demand with hybrid heat pumps with hydrogen boilers. The hydrogen boilers assist the heat pump at cold periods $\left(<-5^{\circ} \mathrm{C}\right)$, and for tap water production, so the houses are heated comfortably while demand peaks are reduced. The remainder of the electricity demand peak $\left(3.8 \mathrm{MW}_{\mathrm{el}}\right)$ is shaved by the $1 \mathrm{MW}_{\mathrm{el}}$ fuel cell, preventing grid reinforcement.

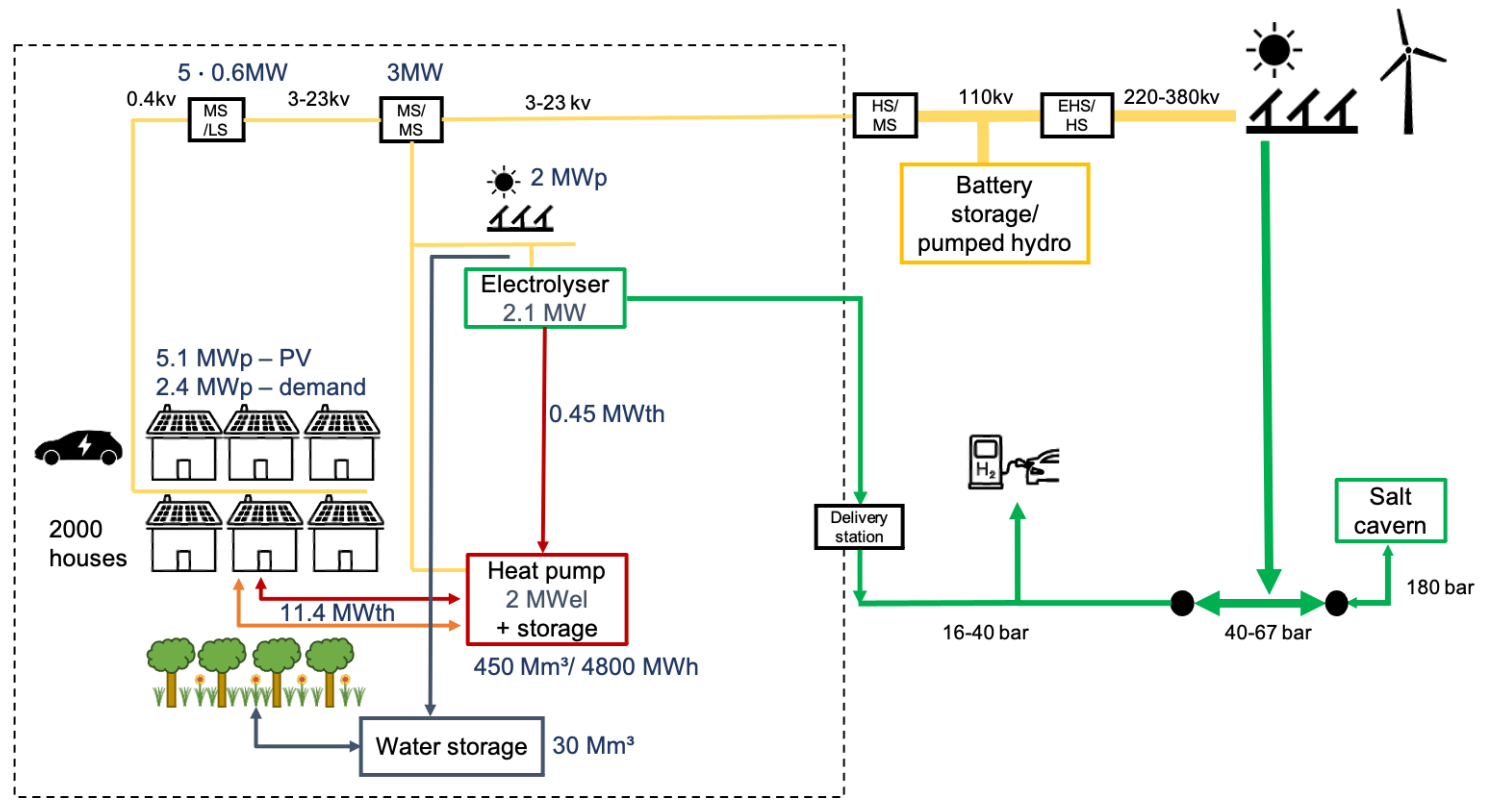

Figure 6. Schematic overview of the power-to-X scenario with both power-to-heat and power-to-hydrogen combined, including using heat from the electrolyzer for the heat storage system. The electricity supply peaks are shaved by the electrolyzer $\left(2.1 \mathrm{MW}_{\mathrm{el}}\right)$ and the heat pump $\left(2 \mathrm{MW}_{\mathrm{el}}\right)$. The heat pump produces heat in summer with surface water as a heat source and stores heat locally in aquifers (HT-ATES). The heating demand of the houses is fulfilled by a low-temperature district heating network $\left(40^{\circ} \mathrm{C}\right)$, with booster heat pumps for tap water production. 
We now discuss the differences between the system designs of the scenarios. The general scheduling strategy is applied to all scenarios (see Section 2.1), and only deviations are mentioned. Energy demand and supply parameters are mentioned if they are not yet included in Table 4.

\subsection{All-Electric}

The first scenario takes an all-electric approach and has no local conversion techniques in place (Figure 3). It represents a reference model for a renewable energy system in a neighborhood based on complete electrification, so with one energy carrier and limited system integration. It does have a local battery of $4 \mathrm{MWh}$ to increase the amount of locally used energy within the neighborhood. In this scenario, the houses need to be retrofitted thoroughly to provide both space heating and domestic hot water with air sourced heat pumps. The maximum peak demand in this scenario will be $4.6 \mathrm{MWp}$, and the supply peak is $5.1 \mathrm{MWp}$, which means there is a need for grid reinforcement because the electricity demand and supply peak are higher than the current grid capacity (3 MW), mainly due to the heat pumps and PV systems. The battery will not be able to reduce this peak capacity because it is empty when the demand peak occurs (in the early morning hours during winter) and full when the supply peak occurs (in summer at the middle of the day).

\subsection{All-Electric $\mathrm{H}_{2}$}

In this mode of system integration, we introduce power-to-hydrogen for peak shaving of locally produced electricity. Simultaneously, there is the option to produce electricity from hydrogen with a fuel cell to provide a part of the electricity demand. Concerning the scheduling strategy, we have chosen to deploy the fuel cell as a baseload in the system. This means that the fuel cell is first used to produce electricity before electricity is imported from the grid. Hydrogen import is thus favored over electricity import here because only installing a fuel cell as a demand peak shave unit results in a very low usage (ca. $0.3 \%$ of the year), resulting in high OPEX costs that could be reduced by increasing the number of full load hours. Therefore, we will be able to investigate the effect of importing large amounts of hydrogen in a neighborhood on system costs. The battery is removed in this scenario because the electrolyzer and fuel cell takes over its function. The size of both the electrolyzer (2.1 MW) and fuel cell $\left(1.75 \mathrm{MW}_{\mathrm{el}}\right)$ are chosen such that grid reinforcement is no longer necessary. The houses still need to be very well insulated (label A).

\section{4. $\mathrm{H}_{2} \mathrm{Hybrid}$}

In $95 \%$ of the (existing) neighborhoods in the Netherlands, there is a natural gas network [54]. It could be an option to reuse the existing gas infrastructure for hydrogen $[58,80]$, further explored in this scenario. It is thus again a form of power-to-hydrogen, like the all-electric $\mathrm{H}_{2}$ scenario. In this mode, we use hydrogen directly as an energy carrier in the house itself. We look at a combination of a hybrid heat pump with hydrogen as a backup for cold periods $\left(<-5^{\circ} \mathrm{C}\right)$ when the heat pump has a low-efficiency, and for domestic hot water production. This hybrid design benefits from the high-efficiency of the heat pump, without the need for electricity grid reinforcement because the hydrogen boiler can take over at times of peak demand. Because the hydrogen boiler can assist the heat pump in creating the necessary heat at a higher temperature, the houses are retrofitted to a lesser extent than the all-electric scenarios (label C). This does however mean that the total heat demand is higher than for the all-electric and all-electric $\mathrm{H} 2$ scenario (see Table 4).

Similar to the all-electric $\mathrm{H}_{2}$ scenario, we have included local hydrogen production with an electrolyzer (2.1 MW) to reduce the supply peaks and a fuel cell $\left(1 \mathrm{MW}_{\mathrm{el}}\right)$ for reduction of the demand peaks (max. 3.8 MWp). The fuel cell is again used as baseload; see in Section 3.3 for a justification. 


\subsection{Power-to-X}

In this mode, we include both power-to-heat and power-to-hydrogen. There is a synergy between those two conversion mechanisms as the heat from the electrolyzer can be used for the district heating system and heat storage. Household heating is provided with a low-temperature district heating network $\left(40{ }^{\circ} \mathrm{C}\right)$. Moreover, small booster heat pumps are installed with a capacity of about $0.5 \mathrm{~kW}_{\mathrm{el}} / 2 \mathrm{~kW}_{\text {th }}$ to produce domestic hot water with $40{ }^{\circ} \mathrm{C}$ as input temperature. Water in the DHN is a closed-loop, and the tap water is produced directly from drinking water and at a higher temperature $\left(60^{\circ} \mathrm{C}\right)$ at the other side of the heat exchanger [81,82]. Therefore, the risk of growth of Legionella, an opportunistic pathogenic bacteria, in water between 20 and $45^{\circ} \mathrm{C}$ is minimized.

Because heat is now merely provided via the DHN, the electricity peak demand of the neighborhood (2.4 MWp) is reduced compared to the other scenarios. As the electricity demand peak is lower than the grid capacity, there is no need to install a fuel cell in this scenario. The heat pump ( $2 \mathrm{MWel}$ ) size is chosen so that enough heat can be provided to the neighborhood in winter. Although the heat pump is $2 \mathrm{MW}_{\mathrm{el}}$ and should be able to reduce electricity production peaks, we still need a $2.1 \mathrm{MW}_{\mathrm{el}}$ electrolyzer. Because at a cold but sunny day in February or the beginning of April, the heat pump is switched off (surface water temperature is too low), while there is still an excess of electricity production from households. The heat pump is thus not suitable to deliver peak shaving capacity throughout the year. Hence, as solar production peaks do happen outside the summer months as well, the electrolyzer is necessary for year-round peak shaving capacity.

\section{Results}

Based on the scenarios described in Section 3, model simulations were performed to determine the energy balance and system costs for each scenario. In this section, we compare the scenarios on their local energy and water use, monthly and yearly energy imports and exports and peaks in demands and supply. As longer-term seasonal subsurface storage is often not included in energy system designs for neighborhoods, we elaborate on the functioning of the HT-ATES system within the power-to-X scenario. Subsequently, a comparison of system costs is presented, including a cost breakdown for different system elements and a sensitivity analysis on hydrogen and electricity costs.

Sankey diagrams of all scenarios are presented in Figures 7-10. Figures visualize the yearly energy and water flows of the different scenarios based on five-year averages. The Sankey diagrams show that the different scenarios vary in their mode of integration. The all-electric scenario has three separate flows for electricity, hydrogen and water and only uses electricity in households. In the other scenarios, the number of interconnections for conversion increases as well as the different energy carriers used. All-electric $\mathrm{H}_{2}$ and $\mathrm{H}_{2}$ hybrid show integrating power-to-hydrogen in different ways. In the fourth mode (power-to-X), power-to-heat is added as well. Moreover, as Figure 10 shows, a connection between power-to-heat and power-to-hydrogen is made by using heat from the electrolyzer for the DHN.

\subsection{Local Energy and WATER USE}

The local energy supply (PV on roofs plus a solar park) in the neighborhood can fulfill $23-30 \%$ of its electricity demands (see Table 5 ). As the battery provides storage of locally produced energy, the amount of locally used electricity is the highest in the all-electric scenario $(27 \%+8 \%=35 \%)$, followed by the power-to-X scenario $(30 \%)$. The other two scenarios have just under $25 \%$ direct local electricity use. 


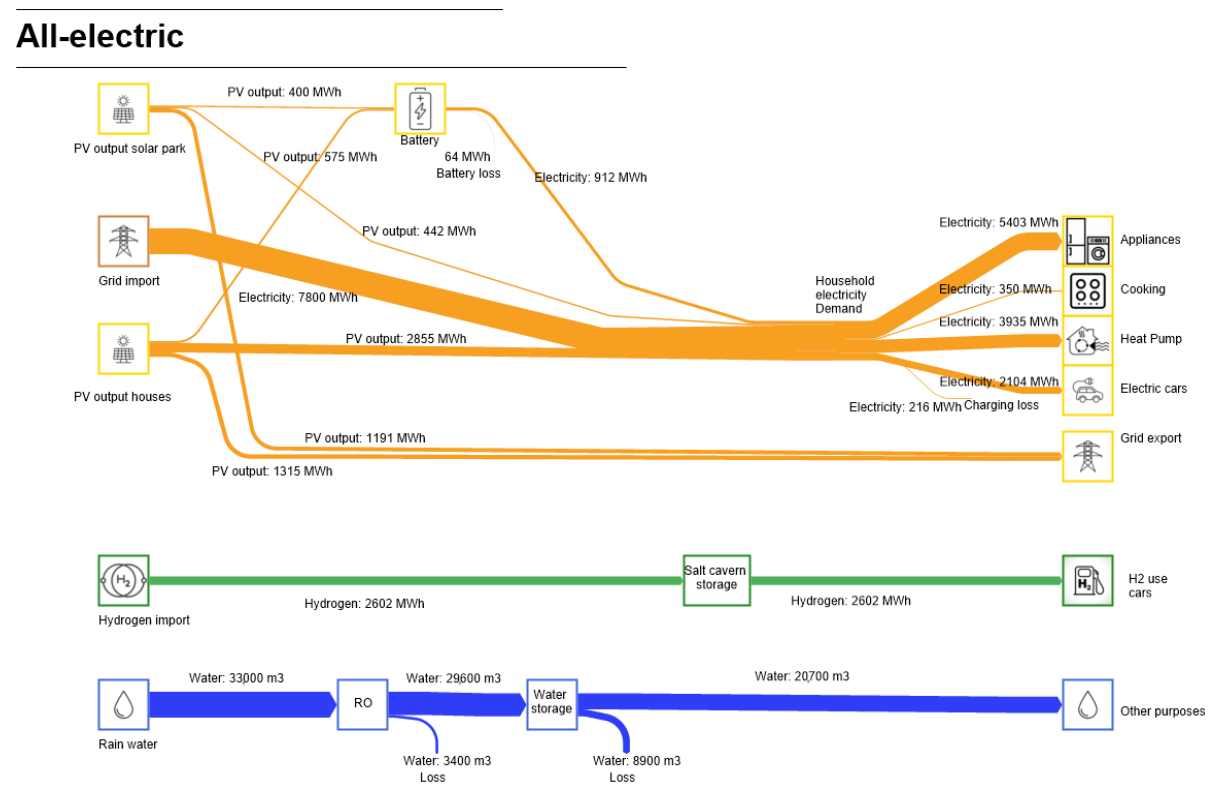

Figure 7. Sankey diagram of the yearly energy and water flows in the all-electric system. Electricity, hydrogen and water are three separate flows without integration. The households solely use electricity as their energy source. Part of their electricity demand (3297 MWh or 27\%) is fulfilled by local PV, 7800 MWh or $65 \%$ by import from the grid and 912 MWh or $8 \%$ by local battery storage. Not all locally produced electricity can be stored in the battery or used directly, which results in $2506 \mathrm{MWh}$ of electricity export to the grid. Losses for electricity conversion will be a few percentage points and are not shown in the Sankey diagrams. This will be done in a later stage of the system design and need to include DC/DC conversion as well.

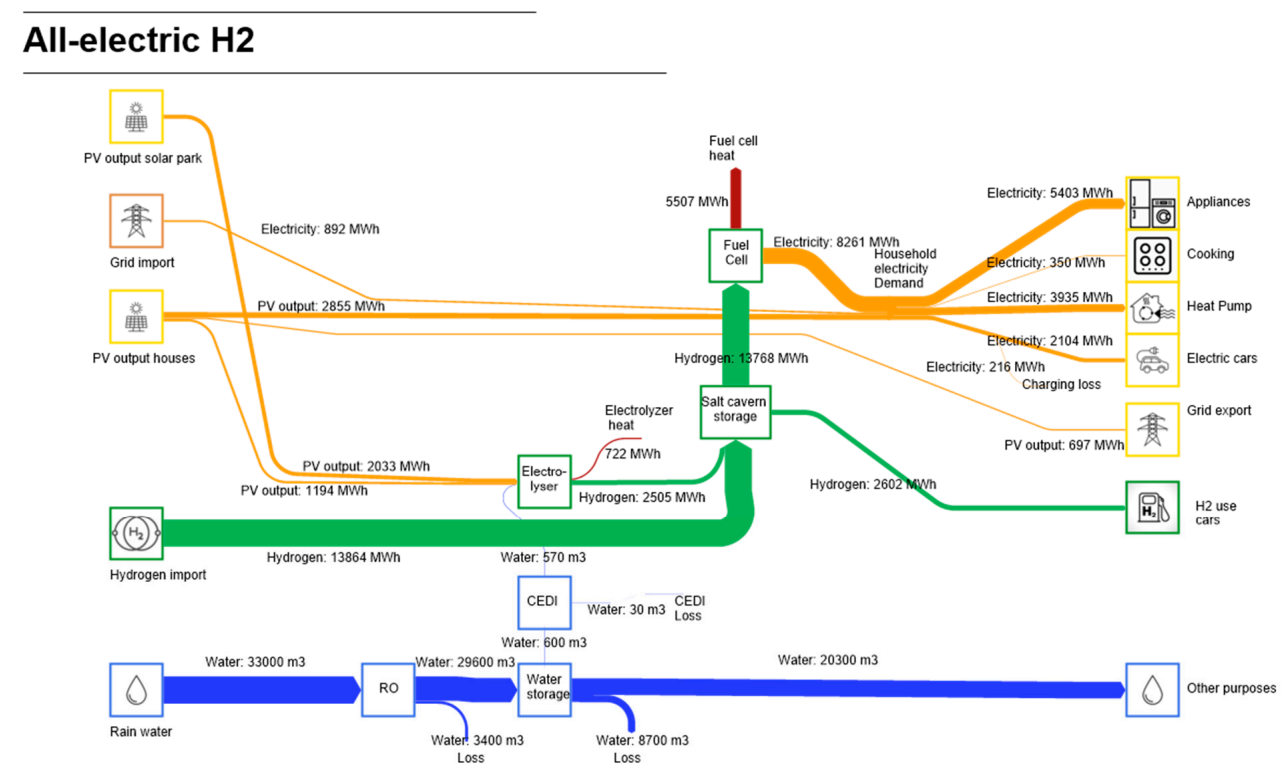

Figure 8. Sankey diagram of the yearly energy and water flows in the all-electric $\mathrm{H}_{2}$ system. Connections between water and hydrogen (for hydrogen production) and hydrogen and electricity (electrolyzer and fuel cell) create a more integrated system in this scenario. The houses have electricity as their only direct energy source. $2885 \mathrm{MWh}$ or $24 \%$ of their electricity demand is fulfilled by direct use of local PV production, and $892 \mathrm{MWh}$ or $7 \%$ is imported from the electricity grid. The remainder of the electricity demand is fulfilled by the import of hydrogen and local conversion of hydrogen to electricity by a fuel cell (8261 MWh or 69\%). Local electricity production that could not be used directly is first converted to hydrogen (3227 MWh), and if the electrolyzer is working at full capacity, the remainder is exported to the grid (697 MWh). 


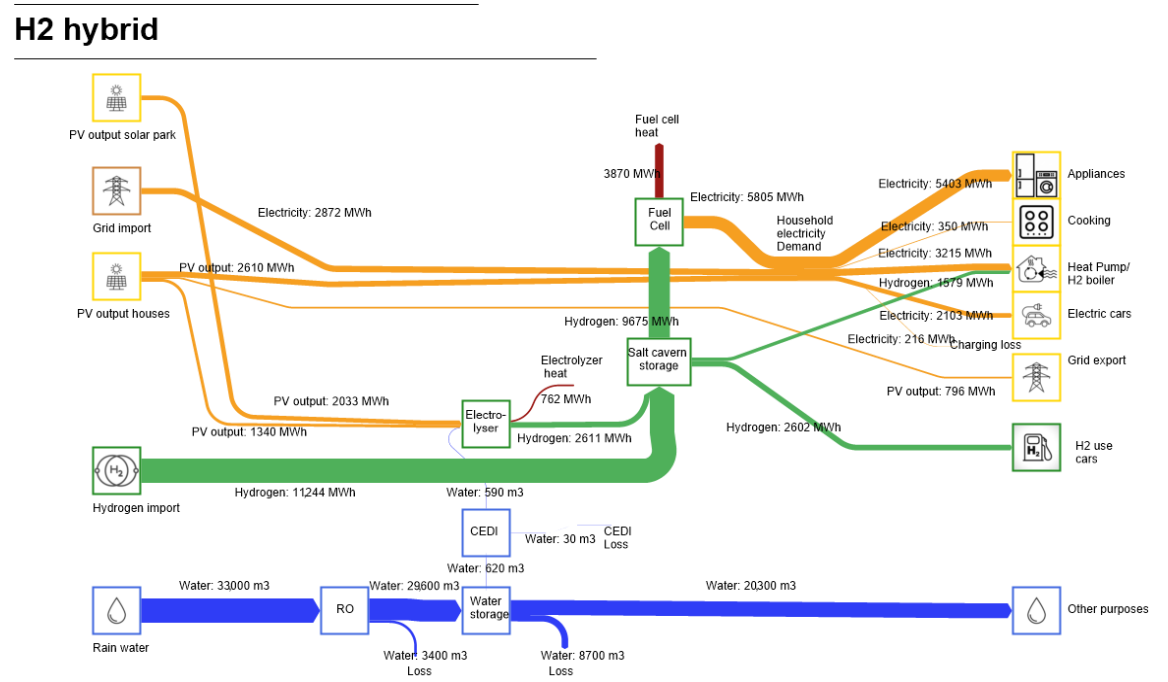

Figure 9. Sankey diagram of the yearly energy and water flows in the $\mathrm{H}_{2}$-hybrid system. The total heat demand ( $\left.4794 \mathrm{MWh}\right)$ is higher than in the all-electric scenarios (3935 MWh) because the houses are retrofitted to a lesser extent. Instead, one extra flow is added as hydrogen is now used in households directly for tap water and space heating in cold periods $\left(<-5^{\circ} \mathrm{C}\right)$, still maintaining a sufficient comfort level. Local PV production fulfills $23 \%$ (2.610 MWh) of the electricity demand, and the $1 \mathrm{MW}_{\mathrm{el}}$ fuel cell provides 52\% (5.803 MWh). As the fuel cell is smaller than in the all-electric $\mathrm{H}_{2}$ scenario, $2.872 \mathrm{MWh}$ (26\%) of the electricity demand is imported from the grid. Local electricity production that could not be used directly is first converted to hydrogen (3373 MWh), and if the electrolyzer is working at full capacity, the remainder is exported to the grid (796 MWh).

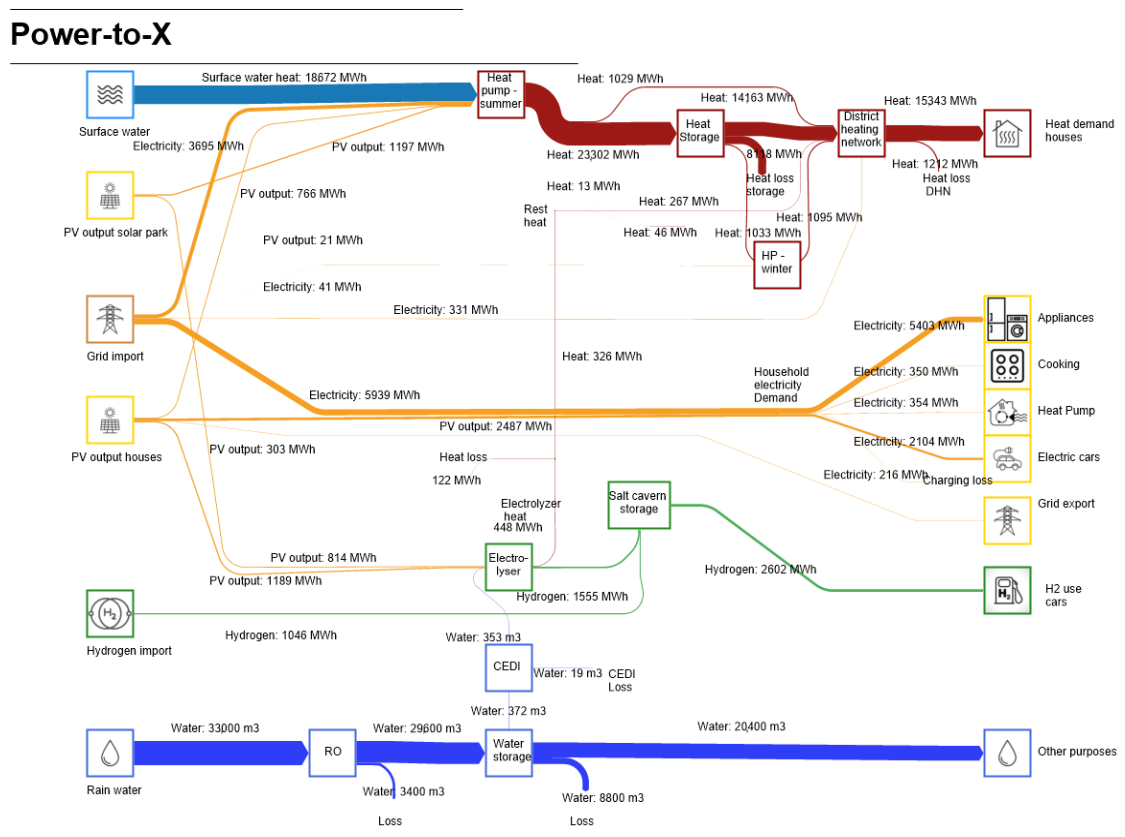

Figure 10. Sankey diagram of the yearly energy and water flows in the power-to-X system. An extra flow is added to the Sankey diagram to show the heat production, storage, and houses' heat demand when a low-temperature district heating system is installed in the neighborhood. The electricity demand of the houses is reduced compared to the other scenarios, as only $354 \mathrm{MWh}$ of electricity is used by the booster heat pumps for tap water production. The district heating network makes a fuel cell for demand peak shaving redundant. The heat pump is shown twice in the Sankey diagram, although only one large-scale heat pump is installed. This large-scale heat pump is used in summer to produce heat (Heat pump summer) and partly in winter as well (HP-winter) to increase the temperature of the heat storage system to a sufficient temperature. 
Table 5. Percentages of the electricity, hydrogen and heat demand arranged per energy carrier (electricity, heat, hydrogen) and scenario.

\begin{tabular}{|c|c|c|c|c|}
\hline & \multicolumn{4}{|c|}{ Electricity } \\
\hline & All-Electric & All-Electric $\mathrm{H}_{2}$ & H2 Hybrid & Power-to-X \\
\hline Direct from RES & $27 \%$ & $24 \%$ & $23 \%$ & $30 \%$ \\
\hline From grid & $65 \%$ & $7 \%$ & $26 \%$ & $70 \%$ \\
\hline From $\mathrm{H} 2$ storage & $0 \%$ & $69 \%$ & $51 \%$ & $0 \%$ \\
\hline \multirow[t]{3}{*}{ From battery } & $8 \%$ & $0 \%$ & $0 \%$ & $0 \%$ \\
\hline & \multicolumn{4}{|c|}{ Hydrogen } \\
\hline & All-electric & All-electric $\mathrm{H}_{2}$ & $\mathrm{H}_{2}$ hybrid & Power-to- $X$ \\
\hline Direct from RES & - & $15 \%$ & $19 \%$ & $60 \%$ \\
\hline \multirow[t]{3}{*}{ From $\mathrm{H}_{2}$ storage } & - & $85 \%$ & $81 \%$ & $40 \%$ \\
\hline & \multicolumn{4}{|c|}{ Heat } \\
\hline & All-electric & All-electric $\mathrm{H}_{2}$ & $\mathrm{H}_{2}$ hybrid & Power-to- $X$ \\
\hline $\begin{array}{l}\text { From electricity } \\
\text { (grid/RES) }\end{array}$ & $100 \%$ & $100 \%$ & $67 \%$ & $10 \%$ \\
\hline From hydrogen & - & - & $33 \%$ & - \\
\hline From heat storage & - & - & - & $90 \%$ \\
\hline
\end{tabular}

Next to electricity, there is local hydrogen production as well. The electrolyzer functions mainly as a peak shaver and only works on local RES supply. Still, the hydrogen mobility demand can be fulfilled for $60 \%$ (power-to-X) to above around $100 \%$ (all-electric $\mathrm{H}_{2}$ and $\mathrm{H}_{2}$ hybrid) by local hydrogen production.

However, despite the local energy production, a considerable amount of energy import is necessary for all scenarios. This shows that even in a neighborhood with a high potential for PV plus some extra local production, there is still a high dependence on energy imports if all energy consumption sectors are considered.

From the roofs and PV-park, a total of $33,000 \mathrm{~m}^{3}$ of rainwater can be collected each year (see Sankey diagrams). The amount of pure water needed for the electrolyzer is about $340 \mathrm{~m}^{3} /$ year, about $1 \%$. If the entire water supply stream would be treated by an RO installation, $30,000 \mathrm{~m}^{3}$ of water is available (after first treatment) for other water demands. If this excess water would be stored in a subsurface storage system, on average, 20,500 $\mathrm{m}^{3}$ of water would be available - after recovery—for other purposes in the neighborhood.

\subsection{Import and Export of Energy}

In terms of total energy import, the all-electric scenario has the lowest amount of total import (10.9 GWh/year, electricity and hydrogen import combined), followed by the power-to-X scenario (11.2 GWh/year). The other scenarios have more hydrogen imports, which reduces the import from the grid but increases the total energy imported in the system to around $15 \mathrm{GWh}$ /year in total. As expected, most energy exports and conversion of energy to hydrogen and heat occur during the summer months. In an all-electric scenario, $37 \%$ of the locally produced electricity is exported to the grid. This decreases to $10 \%$ (hydrogen scenarios) and $5 \%$ for the power-to-X scenario.

The role of conversion and storage on the import and export varies highly per scenario. The battery of $4 \mathrm{MWh}$ in the all-electric scenario can provide $8 \%$ of the total electricity demand (see Table 5), whereas $65 \%$ of the energy demand is imported from the grid. In contrast, the all-electric $\mathrm{H}_{2}$ scenario imports $70 \%$ of its energy from (central) hydrogen storage, and the $\mathrm{H}_{2}$ hybrid system $50 \%$. The power-to-X system has the highest percentage of electricity demand fulfilled by the grid $(70 \%)$. In contrast, the heat demand in the power-to-X scenario is fulfilled for $85 \%$ by the HT-ATES. The $\mathrm{H}_{2}$ hybrid scenario has its heat demand fulfilled by a combination of electricity $(70 \%)$ and hydrogen $(30 \%)$, while the all-electric scenarios completely fulfill their heat demand with electricity. This variation in heat sources and retrofitting level leads to a difference in energy use for heat pumps, as shown in the Sankey diagrams. 
More insight into yearly variations can be obtained from Figure 11, where each monthly bar shows the amount of energy import (positive value) and export/storage (negative value). Again, we see a pattern where scenarios with a (baseload) fuel cell have more hydrogen import and higher energy demand. The power-to- $X$ scenario has the most balanced energy demand profile over the year because a significant amount of energy is imported during summer to produce and store heat, which is used during winter.

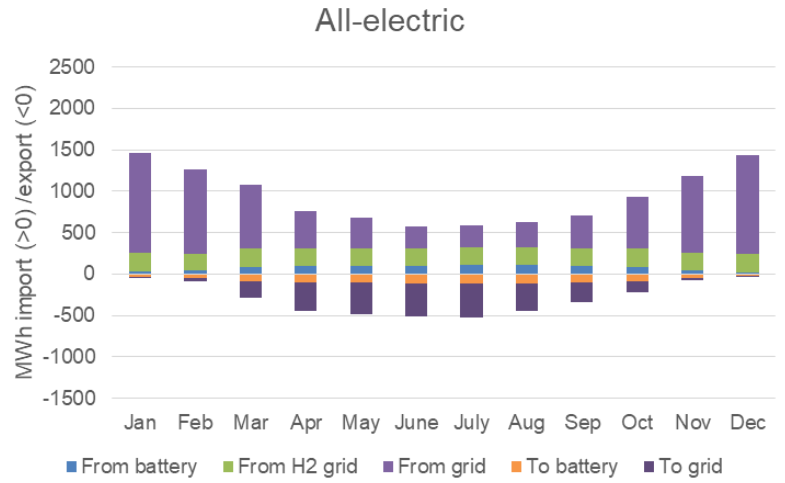

All-electric - $\mathrm{H} 2$

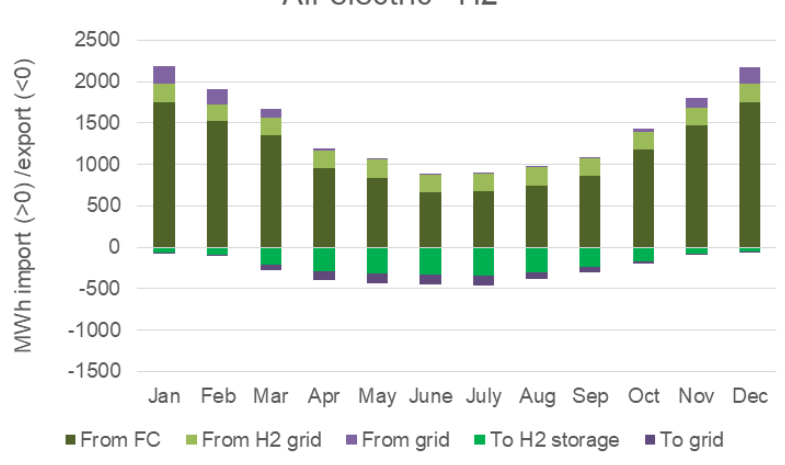

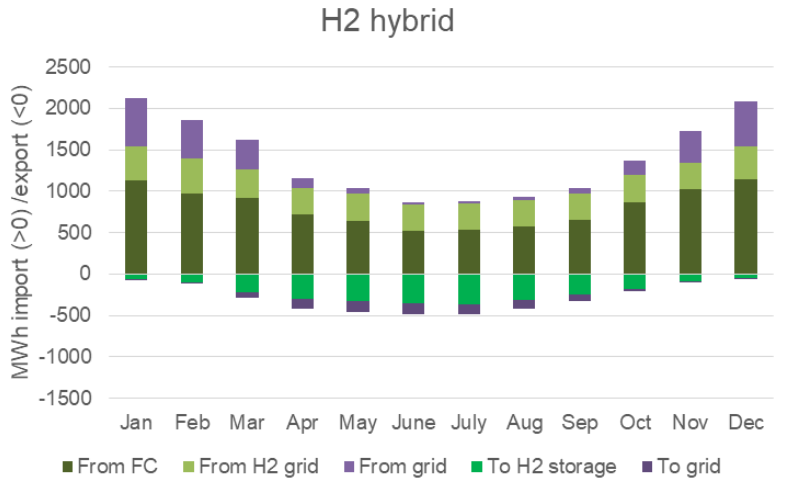

Power-to-X

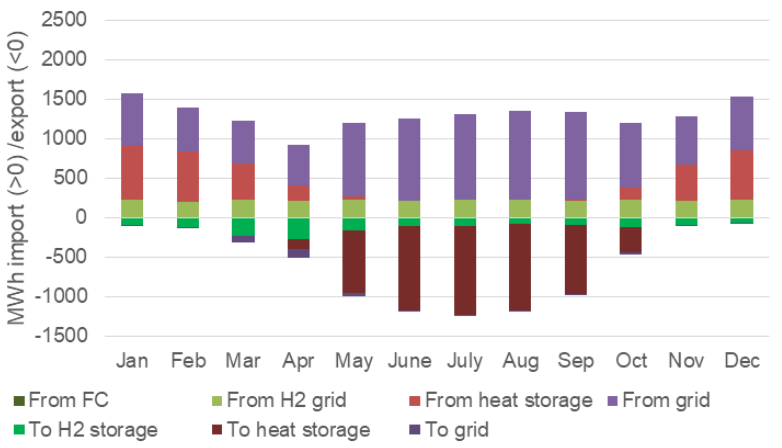

Figure 11. Monthly energy balance of the four scenarios, positive values represent energy use, while negative values show the energy that is stored or exported. The all-electric scenario has the lowest overall energy demand because it has the least conversion losses. The all-electric, all-electric $\mathrm{H}_{2}$ and $\mathrm{H}_{2}$ hybrid systems all show a seasonal pattern of lower energy demand and more export in summer, and higher energy demand and less export in winter. The power-to- $X$ scenario has a more distributed energy demand pattern, as in summer, heat is produced with the large-scale heat pump (with surface water as a source), and heat is stored for use in winter.

\subsection{Peaks in Energy Demand and Supply}

The scenarios have different peaks in demand and supply. An example is shown in Figure 12, visualizing the net electricity demand of the neighborhood on a (very) cold day in February 2012. Although cold, this day was sunny with enough production from the roof solar PV systems to fulfill the electricity demand in the middle of the day. This peak in PV production explains the sharp decline in electricity demand from the grid.

How heat demand is fulfilled is the determining factor that leads to the differences between the graphs. The all-electric scenario fulfills the heat demand completely with electricity, thereby creating a higher peak demand than the current maximum grid capacity (black line). Therefore, the grid capacity in this scenario needs to be increased. The allelectric $\mathrm{H}_{2}$ has the same electricity demand profile, but in this case, the fuel cell reduces the peak demand in the morning and evening. In the $\mathrm{H}_{2}$-hybrid scenario, the hydrogen boiler provides most of the heat demand as long as the temperature is below $-5{ }^{\circ} \mathrm{C}$. The explanation for the little peak around $3 \mathrm{pm}$ is the heat pump switched on because the temperature is just above $-5^{\circ} \mathrm{C}$, while the rooftop PV systems are not fully covering this demand. From 4 pm onwards, the hydrogen boiler provides the heat again as the 
temperature drops below $-5{ }^{\circ} \mathrm{C}$. Lastly, in the power-to- $X$ scenario, the district heating network does provide most of the heat demand plus a little electricity demand for the booster heat pump producing tap water, but overall, the electricity demand stays well below $3 \mathrm{MW}$ for the neighborhood as a whole.

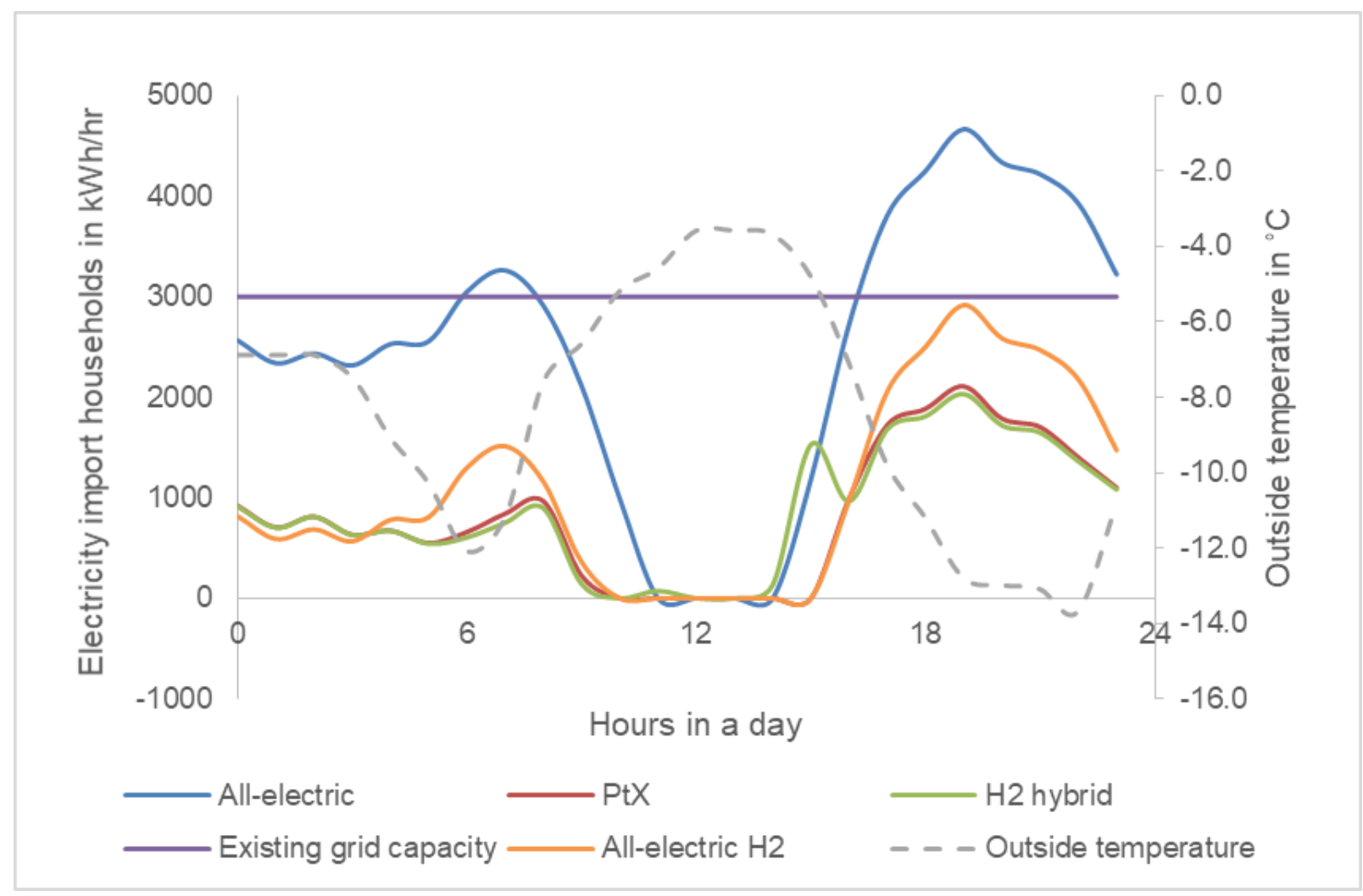

Figure 12. Neighborhood peak demands during a very cold day of the simulation period (6 February 2012), with the outside temperature on the second (right) axis. $\mathrm{PtX}$ is the power-to-X scenario. The current maximum grid capacity ( $3 \mathrm{MW}$ ) is shown as a purple line. The all-electric scenario exceeds the current maximum grid capacity of the neighborhood due to high electricity demand for heat pumps, combined with other electricity demand (cooking, appliances, electric car) in the evening hours. The other scenarios have different ways to lower the demand peak, either by shaving the peak with a fuel cell (all-electric $\left.\mathrm{H}_{2}\right)$, using hybrid heat pumps with hydrogen boilers $\left(\mathrm{H}_{2}\right.$ hybrid), or a district heating network to fulfill the heat demand $(\mathrm{PtX})$. Another interesting finding is that this cold day was sunny as well, which explains the low electricity import in the middle of the day when the roof PV systems fulfill the electricity demand of the households.

The example given here is, of course, an exceptional situation. Nonetheless, the peak in electricity demand in the all-electric scenario is not an exception. During the runtime analyzed (2010-2014), the electricity demand exceeds the existing grid capacity about a hundred times a year in the all-electric scenario. In the other scenarios, the peak demand never exceeds the current grid capacity due to the deployment of the fuel cell or the existence of a DHN.

At times of peak supply from PV on roofs and the solar park, the all-electric scenario has a battery to shave those peaks, while the other scenarios have a $2.1 \mathrm{MW}_{\mathrm{el}}$ electrolyzer. In Figure 13 is illustrated how on two sunny days in April, the battery in the all-electric scenario cannot store the PV production peaks. Around noon, the battery is already full and unable to reduce the production peaks between 12 and 2 p.m. This is not the case for the other scenarios because they have the electrolyzer and/or heat pump to reduce the peak at every hour of the day. 


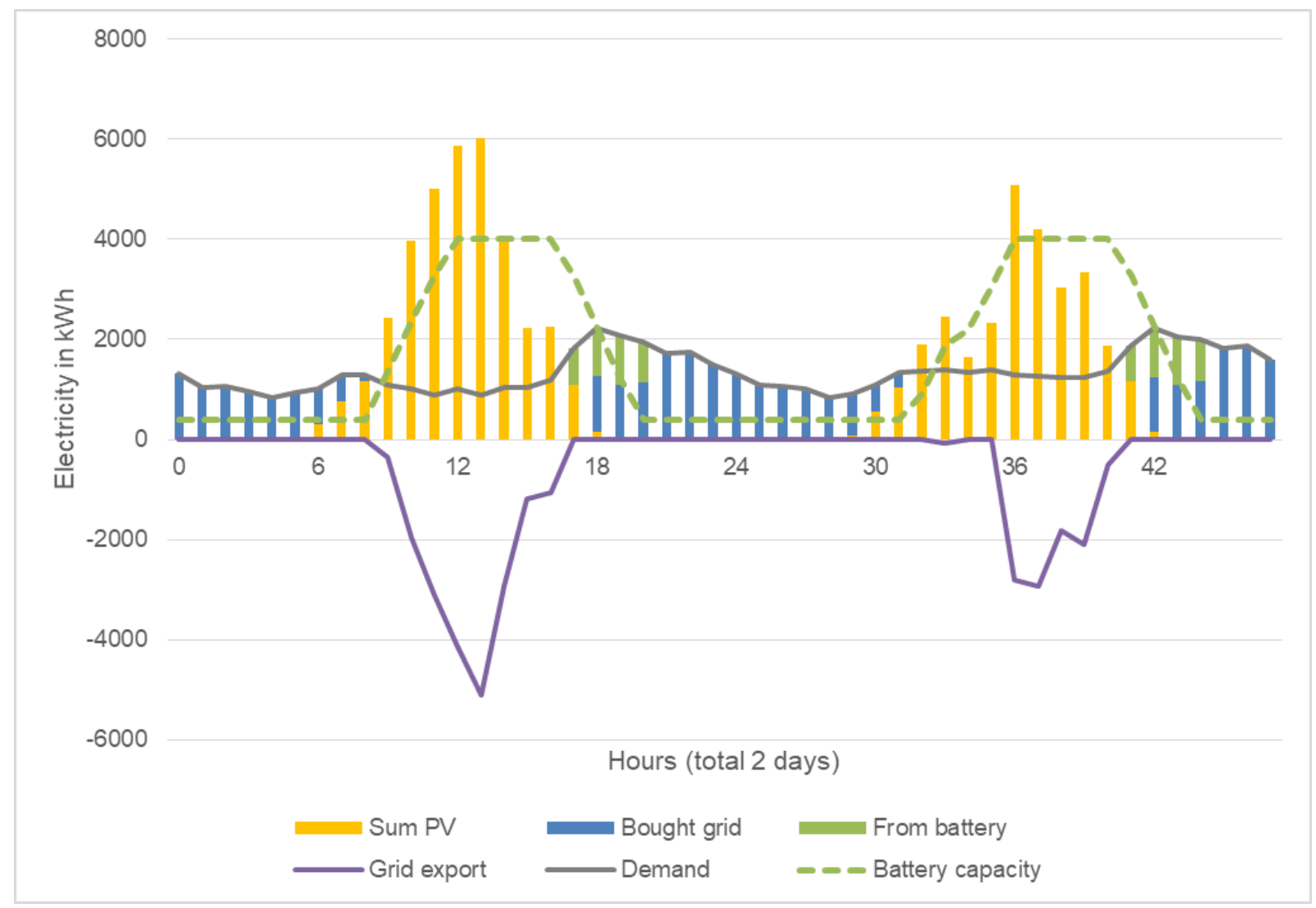

Figure 13. Battery dynamics of the all-electric scenario during two days in April 2010. The graph shows how the energy demand (demand) is fulfilled with PV (sum PV), electricity from the grid (bought grid) and from battery (from battery). The surplus energy is first stored in the battery (battery capacity), and when the battery is full (4 MWh), energy is exported to the grid (grid export).

The electrolyzer is used as a peak shaver and runs only on local renewable electricity. This design choice impacts the load factor of the electrolyzer, which is between 14 and $18 \%$ (ca. 1200-1800 full load hours); see Table 6. The industrial heat pump has a higher load factor $(33 \%)$ than the electrolyzer because it can import electricity from the grid to store enough heat for the winter. In the three scenarios in which a fuel cell is installed, it has a $>50 \%$ load factor because it is utilized as a baseload unit. This means that fuel cell capacity is used first to produce electricity before electricity is imported from the grid.

\subsection{Zooming in on Long-Term Heat Storage}

The power-to- $X$ scenario includes HT-ATES, where heat is stored in aquifers. During heat storage, water is extracted from a warm well, heated, and injected in a hot well. During heat supply, the opposite happens, groundwater is extracted from the hot well, exchanged with the return flow of the DHN via a heat exchanger and reinjected in the warm well. The groundwater temperature at the wells changes during the simulated time of five years and is shown in Figure 14. During the first phase of the winter, water from the hot well is used directly to exchange heat with the return flow of DHN. At some point during the winter, the heat storage system has cooled down too much to deliver heat directly to the DHN. At that point, the HT-ATES system starts to use the heat pump to provide heat at the right temperature in the most efficient way (see Supplementary Materials Section 3.3 for the details on the exact operating strategies of the heat pump combined with the HT-ATES wells). This also results in a sharp decrease of the warm well temperature as the heat pump allows for further cooling of the flow entering the warm well, see arrow in Figure 14. The yearly stored volume during heat supply and storage is $700,000 \mathrm{~m}^{3}$ on average and 
changes somewhat over time (see Table 7). For the five simulated years, the average heat recovery efficiency is $71 \%$. The recovery efficiency varies per year. If there has been a slight oversupply of heat in one year compared to the actual heat demand, the heat that stays behind in the aquifer can be reused in the next year. This effect explains why the recovery efficiency can sometimes be above $100 \%$.

Table 6. Load factors of main system components for all scenarios, based on a five-year average.

\begin{tabular}{ccccc}
\hline Load Factors in \% & All-Electric & All-Electric $\mathbf{H}_{\mathbf{2}}$ & $\mathbf{H}_{\mathbf{2}}$ Hybrid & Power-to-X \\
\hline Heat pump & - & - & - & 33.0 \\
Electrolyzer & - & 17.5 & 18.3 & 10.9 \\
Fuel cell & - & 53.9 & 66.2 & - \\
PV park & 11.4 & 11.4 & 11.4 & 11.4 \\
PV houses & 9.5 & 9.5 & 9.5 & 9.5 \\
\hline
\end{tabular}

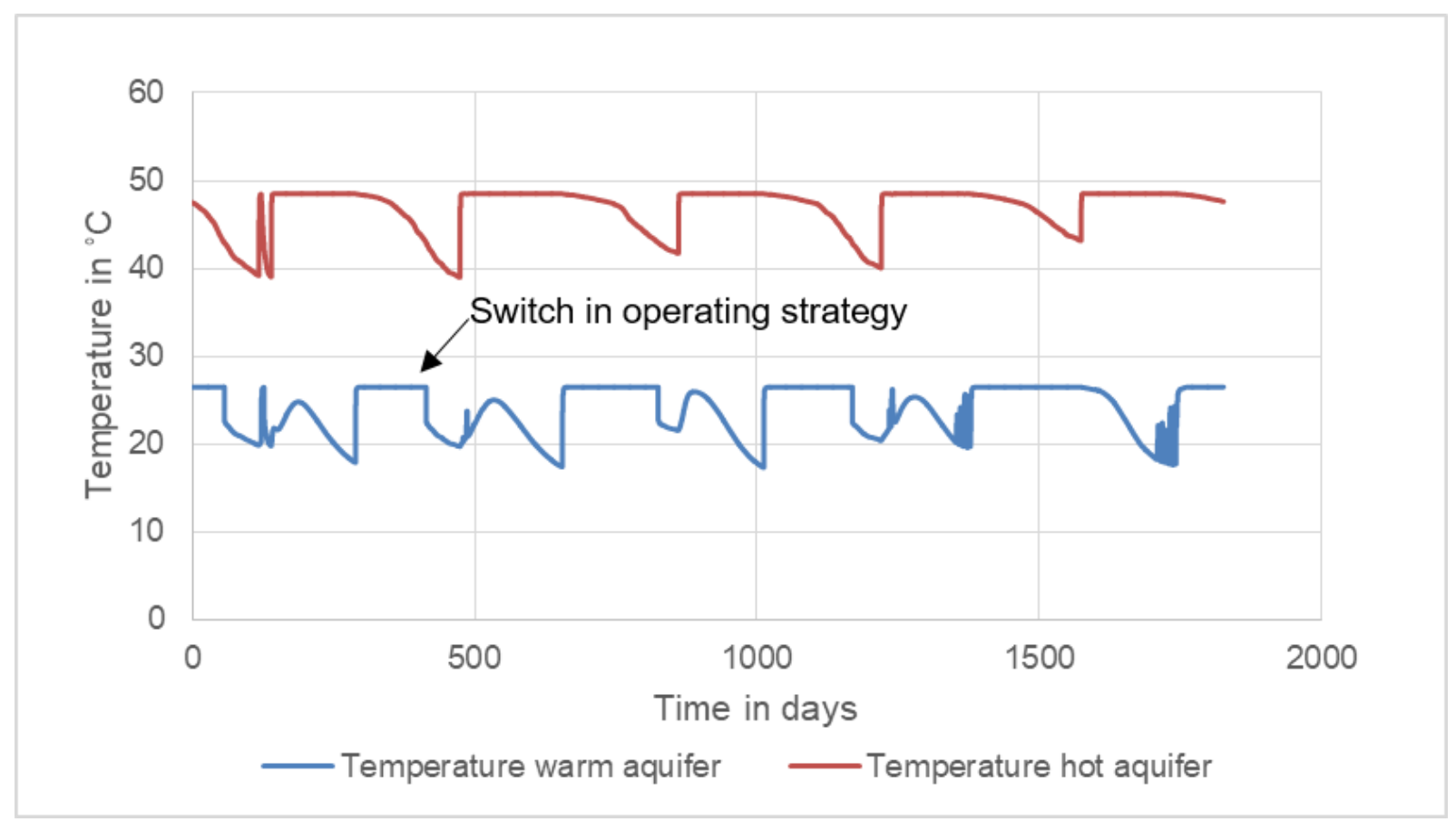

Figure 14. Temperature of the hot and warm well over five years (2010-2015). The last five years of ten years of modeling are shown, as the first five years were used to heat up the wells starting from background temperature $\left(12^{\circ} \mathrm{C}\right)$. After five years, the system has reached an equilibrium state. The arrow shows the switch to a different operating strategy (see text) and a decrease in the warm well temperature.

Table 7. Overview of the HT-ATES performance over five years, starting from the sixth year that the system is running after it has been warmed up in years $1-5$.

\begin{tabular}{|c|c|c|c|c|c|c|c|}
\hline & $\begin{array}{l}\text { Hot Well } \\
\text { Efficiency }\end{array}$ & $\begin{array}{l}\text { Warm Well } \\
\text { Efficiency }\end{array}$ & $\begin{array}{c}\text { Yearly System } \\
\text { Efficiency }\end{array}$ & $\begin{array}{l}\text { Heat Storage } \\
\text { (TJ) }\end{array}$ & $\begin{array}{l}\text { Heat Supply } \\
\text { (TJ) }\end{array}$ & $\begin{array}{l}\text { Volume Storage } \\
\quad\left(-1000 \mathrm{M}^{3}\right)\end{array}$ & $\begin{array}{l}\text { Volume Supply } \\
\quad\left(-1000 \mathrm{M}^{3}\right)\end{array}$ \\
\hline Year 6 & $103 \%$ & $68 \%$ & $85 \%$ & 72.8 & 63.0 & 717 & 747 \\
\hline Year 7 & $64 \%$ & $109 \%$ & $54 \%$ & 80.8 & 43.7 & 788 & 522 \\
\hline Year 8 & $85 \%$ & $84 \%$ & $70 \%$ & 71.9 & 51.0 & 728 & 604 \\
\hline Year 9 & $95 \%$ & $81 \%$ & $81 \%$ & 68.0 & 56.0 & 696 & 666 \\
\hline Year 10 & $71 \%$ & $102 \%$ & $59 \%$ & 67.2 & 39.9 & 689 & 472 \\
\hline Average & $84 \%$ & $89 \%$ & $71 \%$ & 72.1 & 50.7 & 724 & 602 \\
\hline
\end{tabular}

The heat demand of the neighborhood is fulfilled $85.5 \%$ of the time from the HTATES system. Another 13\% of the heat is used directly after production before it could be stored. The heat from the electrolyzer and fuel cell fulfills $1.5 \%$ of the heat demand. Lastly, electricity is used to elevate the return temperature of the $\mathrm{DHN}$ in winter when the 
hot well temperature decreases below $43{ }^{\circ} \mathrm{C}$. This electricity use amounts to $<1 \%$ of the heat demand. To produce the heat, a total of $5720 \mathrm{MWh}$ of electricity is used by the heat pump, of which 1985 MWh came from local RES production and 3735 MWh from the grid (derived from Figure 10).

\subsection{Economic Results}

Table 8 shows the volumes of electricity and hydrogen bought and sold in each scenario, as well as the CAPEX of the system and the yearly costs per household for electricity, mobility and heat (excluding taxes). In Figure 15, a breakdown of the costs per household per year is shown. The costs include bars for discounted CAPEX plus OM cost and separate bars for electricity/hydrogen import costs. Some of these costs will most probably be made by, for instance, the grid operator (grid reinforcement) or the heat provider (heat pump). Here we show the discounted costs if the costs made for a certain scenario would be divided over all households, so they represent the societal costs and are mainly meant for a fair comparison between the scenarios.

Table 8. Economic results of the four scenarios.

\begin{tabular}{|c|c|c|c|c|}
\hline & All-Electric & All-Electric $\mathrm{H}_{2}$ & $\mathrm{H}_{2}$ Hybrid & Power-to-X \\
\hline Total electricity bought (MWh/year) & 7780 & 890 & 2870 & 9680 \\
\hline Total electricity sold (MWh/year) & 2510 & 700 & 800 & 300 \\
\hline Total H2 used (ton/year) & 66 & 415 & 340 & 66 \\
\hline Total H2 produced (ton/year) & 0 & 64 & 66 & 36 \\
\hline Total CAPEX system (M€) & 47 & 46 & 24 & 40 \\
\hline OM system (M€/year) & 1.0 & 1.0 & 1.4 & 1.0 \\
\hline $\mathrm{E}_{\text {cost }}$ system (electricity $+\mathrm{H}_{2}$ in $\mathrm{M} € /$ year) & 1.0 & 1.1 & 1.2 & 1.2 \\
\hline Discounted investment costs ( $€ /$ year/household) & 1820 & 1800 & 1480 & 1480 \\
\hline Electricity import costs $(€ /$ year / household $)$ & 400 & 30 & 140 & 550 \\
\hline Hydrogen import costs $(€ /$ year/household $)$ & 100 & 540 & 440 & 40 \\
\hline Costs per household ( $€$ /year)—see Figure 15 for breakdown & 2320 & 2370 & 2070 & 2070 \\
\hline
\end{tabular}

The total CAPEX costs are the lowest for the integration mode with hybrid hydrogen heat pumps, the $\mathrm{H}_{2}$ hybrid scenario (24 M€). In this case, the costs for retrofitting are limited, and the gas network is reused for hydrogen, which saves costs for new infrastructure. The power-to-X scenario with both power-to-heat and power-to-hydrogen is about $16 \mathrm{M} €$ more expensive, mostly due to investments in the district heating network and heat pump. The all-electric and all-electric $\mathrm{H}_{2}$ scenarios are another 6-7 M€ more expensive than power-to$X$. In these scenarios, retrofitting costs (insulation + heat pump) are an important factor in the cost breakdown (Figure 15). For an all-electric system with an air-sourced heat pump, extensive insulation measures are necessary to keep the house warm with a lowtemperature heat system. As the $\mathrm{H}_{2}$ hybrid mode needs less insulated buildings, there is a positive impact on the costs because the hydrogen boiler assists the heat pump at times of peak demand and can deliver higher temperature heat. In line with this result, Table 8 shows a clear distinction between the all-electric and $\mathrm{H}_{2}$ hybrid/power-to- $\mathrm{X}$ scenarios with a yearly cost difference of about 250-300 €/household/year.

If we compare the all-electric scenarios, we observe a similar CAPEX for both, but the OPEX costs of the all-electric $\mathrm{H} 2$ scenario are $100 \mathrm{k} € / \mathrm{y}$ higher, mainly because there is relatively more hydrogen import in this scenario.

The scenario with the most different energy carriers (power-to- $X$ ) has almost 70\% higher system costs than the H2-hybrid system, but the discounted costs per household are the same. The higher investments in the power-to- $X$ system are mainly due to the heat grid (and the industrial heat pump), as these are long-term investments, the yearly discounted costs are quite low. Additionally, the OPEX of the power-to-X system is $400 \mathrm{k} € / \mathrm{y}$ lower than for $\mathrm{H} 2$ hybrid. This is a combined effect of smaller heat pumps, which leads to lower OM costs (as we used a \% of CAPEX for OM costs) and lower OM costs for the DHN (as\% of CAPEX) versus the fixed yearly OM costs for the maintenance of the gas grid. 
The DHN is installed locally, while the gas grid should also be maintained outside of the neighborhood to provide gas from central gas storage locations.

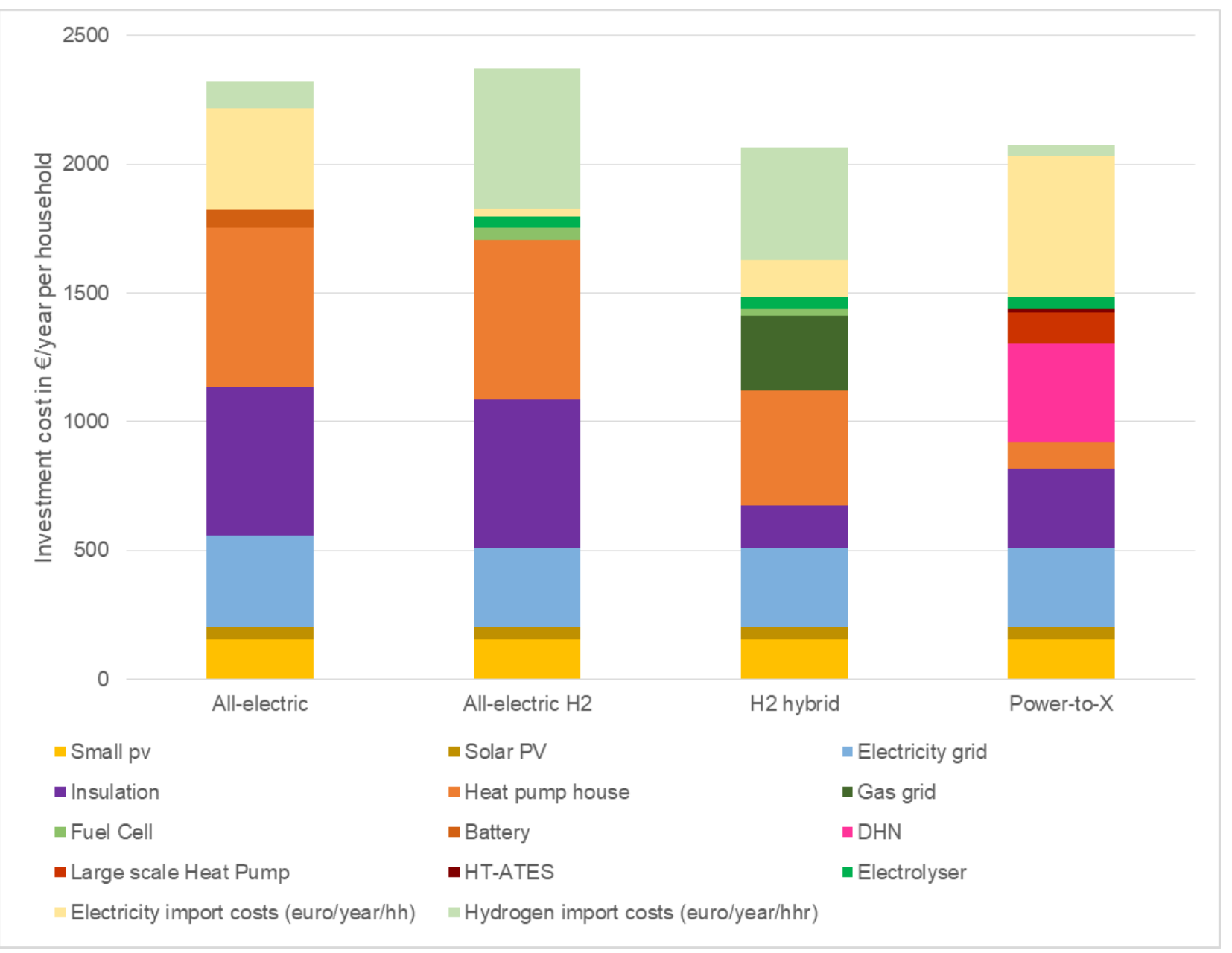

Figure 15. Yearly cost breakdown of the different components in the four scenarios. Costs include discounted CAPEX and OPEX (OM and electricity/hydrogen costs) and are divided over the 2000 households. The all-electric $\mathrm{H}_{2}$ scenario has the highest costs ( $2370 € /$ household/year), mainly due to the high investment costs for insulation (retrofitting from label D to label A), the heat pump and the import costs for hydrogen. The insulation and heat pump costs are important cost factors because those are investments for each individual house. The scenarios with less retrofitting $\left(\mathrm{H}_{2}\right.$ hybrid and power-to- $X$ ) have more costs for conversion, storage and infrastructure (hydrogen and heat), but these costs are shared among all households, resulting in overall lower costs per household.

The storage and conversion installations have a limited contribution to the yearly costs per household, contrasting with the retrofitting/insulation costs (see Figure 15). Although these installations require large investments, when discounted over the lifetime and shared by 2000 households, the contribution to the yearly costs appears to be modest. Infrastructure, on the other hand, has a larger contribution to the cost breakdown, mainly maintenance of the gas infrastructure and the construction and maintenance of a DHN and industrial heat pump. The grid reinforcement costs, however, have a minor contribution to the yearly cost breakdown. In the all-electric scenario, the costs for the electricity grid reinforcement are $50 € /$ household/year, or $2 \%$ of the total costs per household within that scenario. These costs are comparable to the battery ( $70 € /$ household/year) or the electrolyzer ( $50 € /$ household/year).

Two scenarios rely on hydrogen for 80-94\% of their total energy import (all-electric H2 and $\mathrm{H} 2$ hybrid), while the other two (all-electric and power-to-X) rely on 70-86\% electricity import. As there is quite some uncertainty on the prices for both hydrogen as well as 
climate-neutral electricity, we have done a sensitivity analysis on these two economic parameters. The price ranges found in the literature and mentioned in Table 3 are applied. Moreover, we analyzed a low, middle and high price of electricity over a range of hydrogen prices and vice versa. In this way, we get more insight into the combined effect of changes in both prices simultaneously. The results are shown in Figure 16.
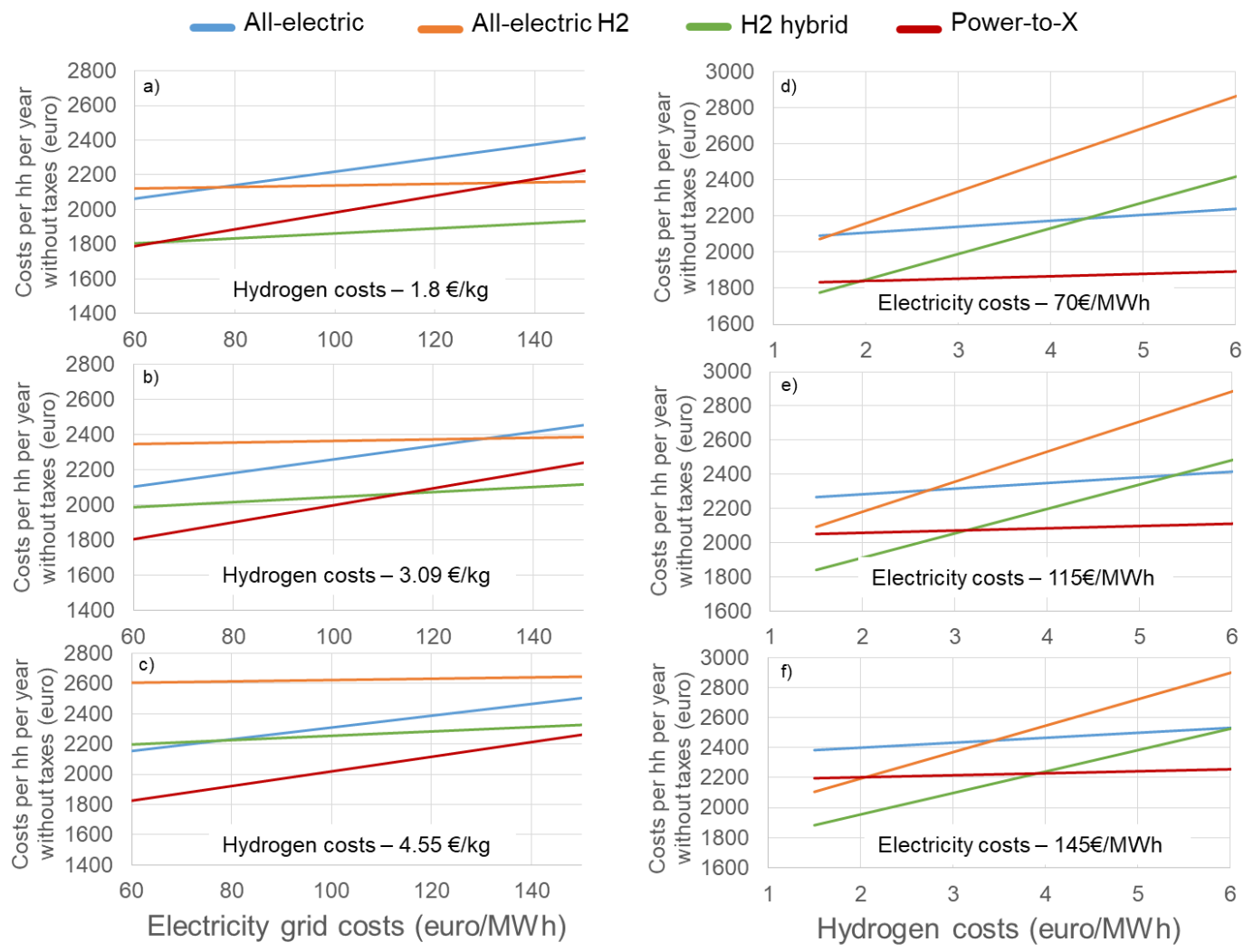

Figure 16. Sensitivity analysis on electricity costs (import from the grid) and hydrogen import costs. The left side shows the sensitivity of the yearly costs per household to the electricity price for climate-neutral electricity, with a fixed hydrogen price in the low (a), middle (b) and high (c) range. The right side shows the sensitivity of the yearly costs per household to the hydrogen costs, with a fixed electricity costs price in the low (d), middle (e) and high (f) range. The middle range values are the values used for the economic analysis in this paper. The analysis shows that the lowest costs option is either the $\mathrm{H}_{2}$ hybrid system or power-to- $X$, which are the systems with the most conversion and storage mechanisms and diversification of energy carriers in the households.

In general, we observe that the competition for the lowest cost option is always between the H2 hybrid and power-to-X scenario. Even with very low electricity prices, especially the costs for retrofitting still make the all-electric scenarios more expensive.

First, we look at varying electricity prices (Figure 16a-c). The electricity price should be lower than $113 € /$ MWh for the power-to-X system to have the lowest system costs (per household) with the average hydrogen price (Figure 16b). If the hydrogen costs turn out to be at the low end of the range $(1.8 € / \mathrm{kg})$, the $\mathrm{H}_{2}$ hybrid scenario will have the lowest system costs as the electricity price is higher than $65 € / \mathrm{MWh}$. Moreover, if the hydrogen costs eventually end up at the high end of the range, the power-to- $X$ system will have the lowest costs over the total electricity price range.

Second, we take a closer look at varying hydrogen prices (Figure 16d-f). The intercepts between the system costs for the $\mathrm{H}_{2}$ hybrid and power-to-X scenario are around 2,3, and $4 € / \mathrm{kg}$ of hydrogen, depending on the electricity costs. With a hydrogen price of $4 € / \mathrm{kg}$, the power-to- $X$ scenario will most certainly be the lowest cost option for all electricity price levels (up until $150 € / \mathrm{MWh}$ ). 


\section{Discussion}

\subsection{Energy Balance}

\subsubsection{Local Production versus Energy Import}

Creating a more integrated energy system has an impact on the energy balance of a neighborhood. System integration modes with power-to-hydrogen (all-electric $\mathrm{H}_{2}$ and $\mathrm{H}_{2}$ hybrid) leads to $30 \%$ less export of locally produced electricity than an all-electric scenario because of local conversion (and partly storage). For a scenario with a combination of power-to-heat and power-to-hydrogen, this is even 35\%. At the same time, the local hydrogen production can fulfill $60-100 \%$ of the hydrogen mobility demand in the neighborhood. On the other hand, every scenario has a high amount of energy import, either in the form of hydrogen or electricity, whereas we already assumed a high potential for solar PV in the neighborhood. Therefore, we expect that the local renewable energy supply can fulfill a maximum of $30-40 \%$ of the total energy demand (heat, electricity and mobility) with currently available PV technology for existing neighborhoods. The import of energy will thus still be important in future energy systems for existing neighborhoods, according to our analysis. This finding is confirmed by other neighborhood studies $[25,83]$.

\subsubsection{More Stable Energy Distribution Pattern with HT-ATES}

The all-electric, all-electric $\mathrm{H}_{2}$ and $\mathrm{H}_{2}$ hybrid scenarios show a seasonal pattern in their energy import due to the higher heating demand in winter (see Figure 11) and, therefore, rely on a central energy storage system. An exception is a power-to- $X$ scenario with a more distributed energy import over the year. In this case, the heat storage is filled during summer, reducing the energy demand in winter. The combination of power-to-heat with local seasonal heat storage systems could thus create more stabilized demand patterns.

\subsubsection{The Impact of Electrolyzer and Fuel Cell Heat Integration on the Energy Balance}

Lastly, we expected the combination of power-to-hydrogen and power-to-heat would benefit the energy balance because the heat from the electrolyzer could be utilized in the DHN or heat storage. However, the results show a modest $1.5 \%$ contribution of the heat from the electrolyzer to the total heat demand. In this system design, there is thus no real added value for the recovery of heat (as it would also require extra installations to recover the heat). In earlier research, we have seen that the electrolyzer could fulfill up to $25 \%$ of the heat demand if the electrolyzer has a higher capacity factor, which means that there still could be a potential of coupling those two conversion technologies [84].

\subsubsection{HT-ATES Recovery Efficiency}

The average yearly system efficiency is $71 \%$, and the hot well efficiency is $84 \%$. The literature on different HT-ATES systems gives values of $78-88 \%$ system efficiency at $100{ }^{\circ} \mathrm{C}$ injection temperature [85], 77-86\% for hot well efficiency at $61^{\circ} \mathrm{C}$ injection temperature [86] or $54-79 \%$ hot well efficiency with a cutoff temperature of $80^{\circ} \mathrm{C}$ [87]. Thus, our findings are within the range or at the higher end of the range compared to the literature. One possible explanation is that the lower injection temperature of $50^{\circ} \mathrm{C}$ positively impacts the recovery efficiency of the hot well. Next to this, other papers often assume a volume balance, while this is not the case for this HT-ATES system. This paper is one of the first to include HT-ATES in analyzing a total neighborhood energy system and shows the potential of this type of seasonal energy storage. Further development and analysis of HT-ATES systems are necessary to get more insight into the potential of this type of seasonal storage within integrated energy systems.

\subsection{Water Supply and Possible Water Demands}

\subsubsection{Rainwater Supply and Storage in the Neighborhood}

In the neighborhood, water could be collected both from roofs as well as from the nearby solar park. In total, $33,000 \mathrm{~m}^{3}$ rainwater/year is available, of which the electrolyzer only needs a fraction $(1 \%)$. Hence, after treatment and storage, approximately $20,500 \mathrm{~m}^{3}$ of 
water is available for other purposes. To make this water available throughout the year, a local storage system needs to be installed. There are multiple reasons to implement local storage and use of rainwater. Rainwater storage systems help to prevent inundation, increase water availability, and plant evaporation has a cooling effect that helps to reduce the urban heat island effect. An example of a large-scale water storage system is an aquifer storage and recovery (ASR) system $[88,89]$. Another smaller scale option is a blue-green roof [90], although such a system is often not combined with solar panels.

\subsubsection{Possible Water Demands}

The storage of collected rainwater could be deployed for plants in (communal or private) gardens, as well as for irrigation of the vegetation in the public spaces of the neighborhood. Furthermore, rainwater has a very low salt concentration $(<20 \mathrm{mg} \mathrm{Cl}-/ \mathrm{L})$ [88], even compared to drinking water (50-130 $\mathrm{mg} \mathrm{Cl-/L)} \mathrm{[91].} \mathrm{This} \mathrm{is} \mathrm{an} \mathrm{advantage} \mathrm{for} \mathrm{the}$ production of pure water because the recovery factor of the RO increases, and there is a slight reduction in energy demand for desalination. Pure water is the source of hydrogen in the electrolyzer. However, next to that, it could be used for more industrial purposes inside or near the neighborhood, such as a car wash or laundry. Purifying rainwater for household purposes is an option as well. The water demand per household is $102.7 \mathrm{~m}^{3} /$ year, of which the toilet, dishwasher and washing machine appear suitable for applying RO-treated rainwater, which would add up to approximately $46 \mathrm{~m}^{3} /$ household/year [92]. The supply of $20,500 \mathrm{~m}^{3}$ would then cover about $20 \%$ of this water demand. A study on rainwater harvesting in the Netherlands found that if water from pavements would be included as well, about $50 \%$ of the water demands of a neighborhood could be covered by rainwater [93]. A more thorough analysis of the possible system layouts, future water demand patterns and costs would be a topic for further research.

\subsection{Peak Demand and Supply}

\subsubsection{The Effect of Power-to-Hydrogen on Peak Demand}

The results in Section 4.3 have shown that integrated system designs that include power-to-hydrogen are better able to deal with peaks in supply and demand than an allelectric scenario. Supply peaks caused by PV production are converted to hydrogen by an electrolyzer, which offers a more continuous capacity for peak shaving than the battery in the all-electric scenario. Moving towards a combination of different energy carriers instead of solely electricity thus has a positive effect on peak demands and supply within the neighborhood. However, we should note here that smart battery use was not thoroughly analyzed, as well as vehicle-to-grid options. If the battery would also be able to import electricity from the grid and provide that at times of high electricity demand, the demand peak in winter could decrease. In combination with the curtailment of PV production peaks in summer, there would probably be less need for grid reinforcement [94]. However, even if smart battery use would be included, we still think our estimation for peak demand in this research is reasonable because of the conservative estimation for peak demand (see Section 3). The option of vehicle-to-grid could also offer flexibility during peak times [95] and would be interesting to include in the model in the future. Including BEV as the battery capacity is, however, subjected to more restrictions than stationary batteries.

\subsubsection{More Potential for Peak Shaving with Power-to-Heat and Power-to-Hydrogen}

In the power-to- $X$ scenario, there could be more room for peak shaving than was shown in the results. The power-to- $\mathrm{X}$ has a similar-sized electrolyzer compared to the other scenarios $\left(2.1 \mathrm{MW}_{\mathrm{el}}\right)$ next to a $2 \mathrm{MW}_{\mathrm{el}}$ heat pump. The electrolyzer could probably be of a smaller size if the heat pump would be used more smartly. At times when the surface water temperature is not high enough, the heat pump is now switched off. An alternative is to increase the temperature in the DHN for a short period to reduce peaks in the local electricity grid. This option was not included in this study but could be looked into in 
future research to further optimize this scenario. Thus, integrating hydrogen or heat could offer even more peak shaving to the energy system than shown in this paper.

\subsubsection{Other Flexibility Services of Power-to-Heat and Power-to-Hydrogen}

Besides reducing local peaks in demand and supply, both the heat pump and the electrolyzer could offer flexibility to the grid by buying at moments when there is an oversupply on the grid. The heat pump has a 33\% load factor, but if only the hours during summer are considered (when the surface water is warm enough), the load factor would be approximately $70 \%$. By shifting the running hours of the heat pump within the summer season, flexibility to the grid could be offered. The potential for load shifting and peak shaving is even higher for the electrolyzer, which currently has a load factor of $14-20 \%$. The potential of offering flexibility to the grid was not analyzed in this study and could not be calculated because fixed electricity prices were used. Although fixed tariffs for consumers may continue to exist, the actual wholesale prices for electricity will become more volatile with high shares of renewables. Other research has shown that offering flexibility with a heat pump $[96,97]$ or electrolyzer $[98,99]$ could be feasible (i.e., targeting low electricity prices) and could be something to apply to these scenarios in future research.

\subsection{System Costs}

\subsubsection{Diversification of Energy Carriers Lead to Lower System Costs}

The sensitivity analysis has shown (see Figure 16) that the "tipping points" for the switch between the $\mathrm{H}_{2}$ hybrid and power-to-X scenario as the lowest cost option are actually within the possible price range of both electricity and hydrogen prices. Yet, we can conclude that in any case, integration modes with more diverse energy carriers (heat, electricity and hydrogen) do lead to lower system costs (250-300 €/year/household) than the all-electric scenarios with electricity as the main energy carrier.

As explained in Section 3.1, this publication has not shown all different possible system designs for neighborhoods. Eventually, every neighborhood has its specific circumstances and (im)possibilities that need to be considered. However, based on the results, it could be interesting to compare more system designs with hydrogen in future research. For example, a design with fuel cell micro-CHP systems could be interesting as they both produce heat and electricity to be used directly within the house. Developments towards reversible hydrogen systems (combined electrolyzer/fuel-cell in one system) have an even larger potential as they can reduce demand and supply peaks at the household level. In summary, we see that modes of system integration with more diverse energy carriers lead to more complex systems, but because they can provide energy in multiple ways, they are more robust.

\subsubsection{Retrofitting as an Important Factor in Energy System Costs}

A factor that is often mentioned as an advantage for integrated systems is the reduction in grid reinforcement costs. However, this analysis shows the grid reinforcement cost within the neighborhood, for the low voltage grid up until the transformer station, is a small factor in relation to the total system costs for end-users, such as households. Alternatively, the costs for insulating existing buildings have shown to be one of the most important cost components that determine the total yearly costs. Because the all-electric modes need a high level of insulation to be compatible with a low-temperature heating system, those scenarios are the most expensive. This is in line with a recent report by the Dutch Environmental Assessment Agency (PBL). The report concluded that the costs for insulation of a house from energy label $D$ to $B$ do not outweigh the energy savings (over 30 years) and are not financially attractive for house owners [100]. 


\subsubsection{Local Hydrogen Production to Electricity Is More Expensive Than Using} Electricity Directly

The all-electric $\mathrm{H}_{2}$ scenario is a mode where hydrogen is introduced as an energy carrier besides electricity and thus integrates more energy carriers in one system. We have seen that introducing more energy carriers leads to lower system costs, but in this case, the all-electric $\mathrm{H}_{2}$ scenario has the highest system costs. Only when the hydrogen costs would be low $(1.8 € / \mathrm{kg})$ and the electricity price above $80 € / \mathrm{MWh}$, the all-electric $\mathrm{H}_{2}$ scenario will be cheaper than the all-electric scenario. The determining factor here is not the grid reinforcement versus the installation of the electrolyzer, as the discounted costs per year are both similar ( $50 € /$ household/year). As both scenarios assume an all-electric heating system, the retrofitting costs are similar as well. In this case, the import costs for hydrogen become the determining factor (see Figure 15). Because of the conversion loss of hydrogen, it is cheaper to have an all-electric system with grid extension than to have local energy production with a fuel cell and hydrogen import (the all-electric $\mathrm{H}_{2}$ scenario). Converting an alternative energy carrier (here hydrogen) to electricity in a central place in the neighborhood leads to higher system costs than an all-electric solution. It is thus more useful to bring alternative energy carriers to the house itself, as was analyzed in the other scenarios.

\subsubsection{The Importance of Hybrid Designs}

Our analysis shows that a hybrid design with hydrogen fulfilling part of the heat demand in households is a favorable option to obtain low system costs for existing neighborhoods. Without a need for thorough retrofitting, a start could still be made with less drastic retrofitting measures, including the installation of a hybrid heat pump, while still maintaining the natural gas boiler. As we have shown, about two-thirds of the heating demand could already be electrified. Over time, the gas boiler could be retrofitted or replaced with a hydrogen boiler or hydrogen-ready boiler, and maybe continue the retrofitting process to further reduce the energy demand. Hybrid systems are an important solution in the smooth transition to a renewable energy system in existing neighborhoods.

\section{Conclusions}

In this paper, we have analyzed four scenarios with different modes of system integration for $100 \%$ renewable energy systems for existing neighborhoods. Moreover, we included several consumption sectors in a neighborhood (electricity, heat, mobility and water). We consider the combination of multiple consumption sectors and energy carriers with local conversion and (seasonal) storage leading to integrated energy-and water systems as a novel aspect of this work. We can conclude that integrating different energy carriers at end-users shows a positive impact on the energy system costs. The integrated system designs with local hydrogen production combined with hybrid hydrogen boilers $\left(\mathrm{H}_{2}\right.$-hybrid) or a low-temperature district heating network, heat storage and hydrogen production (power-to- $X$ ) lead to $250-300 €$ /household/year decrease in cost compared to an all-electric system. In these two modes of system integration, we utilize other energy carriers, such as heat and hydrogen, in the house itself, besides electricity. This diversification of energy carriers decreases the need for extensive retrofitting measures, which have shown to be an important factor in the total system costs.

In the $\mathrm{H}_{2}$ hybrid scenario $2070 €$ /household/year) houses have installed a heat pump and a hydrogen boiler for hot tap water and heat production on cold days. The power-to- $X$ scenario has local heat production and seasonal heat storage (with HT-ATES) and hydrogen production ( $2070 € /$ household/year). The sensitivity analysis has shown that the $\mathrm{H}_{2}$ hybrid system will have the lowest costs if the electricity costs for $100 \%$ renewable electricity are $>120 € / \mathrm{MWh}$ and hydrogen price is below $3 € / \mathrm{kg}$ and the power-to-X system will have the lowest costs if the hydrogen price is above $4 € / \mathrm{kg}$, and the electricity price is $<150 € / \mathrm{MWh}$. At the moment, there is no definitive conclusion to be drawn on which mode of system integration leads to the cheapest system. However, we can conclude that both modes 
of system integration (power-to-heat and power-to-hydrogen) are important to consider, depending on local circumstances and price developments for hydrogen and electricity.

Furthermore, the results show that integrated neighborhood energy systems with local conversion and storage mechanisms (heat or hydrogen) can lower electricity peak demands. Moreover, they have the potential to flatten peaks from the grid at times of oversupply, and only $5-10 \%$ of locally produced energy is exported to the grid. Yet, the percentage of local electricity use is not more than $23-35 \%$ of the total demand, so importing electricity will still be important in future neighborhoods. A seasonal heat storage system leads to the most distributed energy import over the year compared to the other scenarios. Lastly, we have shown that a seasonal heat storage facility (in this study HT-ATES) for a neighborhood is a potentially suitable option for large-scale seasonal heat storage.

In conclusion, this research shows the importance of considering more integrated and hybrid options in designs for future clean, affordable and reliable energy systems for existing neighborhoods.

Supplementary Materials: The Supplementary Materials describing the different model components is available online at https:/ / www.mdpi.com/article/10.3390/en14092616/s1

Author Contributions: Conceptualization, E.v.d.R., T.F. and A.J.M.v.W.; methodology, all authors; software, E.v.d.R., M.B. and S.B.; validation, E.v.d.R. and S.B.; formal analysis, E.v.d.R.; investigation, E.v.d.R. and S.B.; writing—original draft preparation, E.v.d.R.; writing—review and editing, all authors.; visualization, E.v.d.R.; supervision, A.J.M.v.W., J.P.v.d.H., T.F. and M.B. All authors have read and agreed to the published version of the manuscript.

Funding: This activity is co-financed with PPS-funding from the Topconsortia for Knowledge and Innovation (TKI's) of the Dutch Ministry of Economic Affairs and Climate. The authors would like to thank TKI Urban Energy (TEUE117059) in the Netherlands for their financial contribution to the research project that was the foundation for this publication.

Data Availability Statement: All data used are referenced from public sources either in the text or in the Supplementary Materials. Raw data of the modeling results from the scenarios described in the publication can be accessed via https://doi.org/10.4121/14464881.

Conflicts of Interest: The authors declare no conflict of interest.

\section{Abbreviations}

$\begin{array}{ll}\text { BEV } & \text { Battery electric vehicle } \\ \text { CAPEX } & \text { Capital expenditures } \\ \text { COP } & \text { Coefficient of performance } \\ \text { CHP } & \text { Combined heat and power } \\ \text { DHN } & \text { District heating network } \\ \text { DOD } & \text { Depth of discharge } \\ \text { FCEV } & \text { Fuel cell electric vehicle } \\ \text { HHV } & \text { Higher heating value } \\ \text { HT-ATES } & \text { High-temperature aquifer thermal energy storage } \\ \text { kW } & \text { Kilowatt } \\ \text { MILP } & \text { Mixed-integer linear programming model } \\ \text { MW } & \text { Megawatt } \\ \text { GW } & \text { Gigawatt } \\ \text { OPEX } & \text { Operating expenditures } \\ \text { PV } & \text { Photovoltaic } \\ \text { RES } & \text { Renewable energy systems } \\ \text { Subscripts } & \\ \text { el } & \text { electric power } \\ \text { th } & \text { thermal power }\end{array}$




\section{References}

1. REN21. Renewables 2020 Global Status Report; REN21 Secretariat: Paris, France, 2020; ISBN 978-3-948393-00-7.

2. European Energy Agency. Trends and Projections in Europe 2019; Publications Office of the European Union: Luxembourg, 2019; ISBN 9789294801036.

3. European Commission. The European Green Deal. Eur. Comm. 2019, 53, 24. [CrossRef]

4. IEA. Power Systems in Transition; IEA: Paris, France, 2020.

5. $\quad$ REN21. Renewables Global Futures Report; REN21: Paris, France, 2017; ISBN 9783981810745.

6. Parag, Y.; Sovacool, B.K. Electricity market design for the prosumer era. Nat. Energy 2016, 1, 16032. [CrossRef]

7. European Commission. Powering a Climate-Neutral Economy: An EU Strategy for Energy System Integration; European Commission: Brussel, Belgium, 2020.

8. Robinius, M.; Otto, A.; Heuser, P.; Welder, L.; Syranidis, K.; Ryberg, D.; Grube, T.; Markewitz, P.; Peters, R.; Stolten, D. Linking the Power and Transport Sectors-Part 1: The Principle of Sector Coupling. Energies 2017, 10, 956. [CrossRef]

9. Renewable Energy Policy Network. Renewables 2018 Global Status Report; REN21: Paris, France, 2018; ISBN 9783981891133.

10. IRENA. Electricity Storage and Renewables: Costs and Markets to 2030; IRENA: Abu Dhabi, UAE, 2017.

11. IEA. Technology Roadmap: Energy Storage; IEA: Paris, France, 2014.

12. European Commission; Undertaking, F.C.H.J. Commercialisation of Energy Storage; European Commision: Brussel, Belgium, 2015.

13. Mathiesen, B.V.; Lund, H.; Connolly, D.; Wenzel, H.; Ostergaard, P.A.; Möller, B.; Nielsen, S.; Ridjan, I.; KarnOe, P.; Sperling, K.; et al. Smart Energy Systems for coherent 100\% renewable energy and transport solutions. Appl. Energy 2015, 145, 139-154. [CrossRef]

14. Knowledge for Climate Climate Proof Cities. 2014.

15. Oldenbroek, V.; Verhoef, L.A.; van Wijk, A.J.M. Fuel cell electric vehicle as a power plant: Fully renewable integrated transport and energy system design and analysis for smart city areas. Int. J. Hydrog. Energy 2017, 42, 8166-8196. [CrossRef]

16. Robledo, C.B.; Oldenbroek, V.; Abbruzzese, F.; van Wijk, A.J.M. Integrating a hydrogen fuel cell electric vehicle with vehicle-to-grid technology, photovoltaic power and a residential building. Appl. Energy 2018, 215, 615-629. [CrossRef]

17. Robinius, M.; Otto, A.; Syranidis, K.; Ryberg, D.S.; Heuser, P.; Welder, L.; Grube, T.; Markewitz, P.; Tietze, V.; Stolten, D. Linking the Power and Transport Sectors_Part 2: Modelling a Sector Coupling Scenario for Germany. Energies 2017, 10, 957. [CrossRef]

18. Nastasi, B.; Lo Basso, G. Hydrogen to link heat and electricity in the transition towards future Smart Energy Systems. Energy 2016, 110, 5-22. [CrossRef]

19. Orehounig, K.; Evins, R.; Dorer, V. Integration of decentralized energy systems in neighbourhoods using the energy hub approach. Appl. Energy 2015, 154, 277-289. [CrossRef]

20. Wouters, C.; Fraga, E.S.; James, A.M. An energy integrated, multi-microgrid, MILP (mixed-integer linear programming) approach for residential distributed energy system planning-A South Australian case-study. Energy 2015, 85, 30-44. [CrossRef]

21. Siraganyan, K.; Dasun Perera, A.T.; Scartezzini, J.L.; Mauree, D. Eco-SiM: A parametric tool to evaluate the environmental and economic feasibility of decentralized energy systems. Energies 2019, 12, 1-22. [CrossRef]

22. Bloess, A.; Schill, W.P.; Zerrahn, A. Power-to-heat for renewable energy integration: A review of technologies, modeling approaches, and flexibility potentials. Appl. Energy 2018, 212, 1611-1626. [CrossRef]

23. Gabrielli, P.; Gazzani, M.; Martelli, E.; Mazzotti, M. Optimal design of multi-energy systems with seasonal storage. Appl. Energy 2018, 219, 408-424. [CrossRef]

24. Petkov, I.; Gabrielli, P.; Spokaite, M. The impact of urban district composition on storage technology reliance: Trade-offs between thermal storage, batteries, and power-to-hydrogen. Energy 2021, 224, 120102. [CrossRef]

25. Murray, P.; Orehounig, K.; Grosspietsch, D.; Carmeliet, J. A comparison of storage systems in neighbourhood decentralized energy system applications from 2015 to 2050. Appl. Energy 2018, 231, 1285-1306. [CrossRef]

26. Maroufmashat, A.; Fowler, M.; Sattari Khavas, S.; Elkamel, A.; Roshandel, R.; Hajimiragha, A. Mixed integer linear programing based approach for optimal planning and operation of a smart urban energy network to support the hydrogen economy. Int. J. Hydrog. Energy 2016, 41, 7700-7716. [CrossRef]

27. van der Roest, E.; Snip, L.; Fens, T.; van Wijk, A. Introducing Power-to-H3: Combining renewable electricity with heat, water and hydrogen production and storage in a neighbourhood. Appl. Energy 2020, 257. [CrossRef]

28. Brown, T.; Schlachtberger, D.; Kies, A.; Schramm, S.; Greiner, M. Synergies of sector coupling and transmission reinforcement in a cost-optimised, highly renewable European energy system. Energy 2018, 160, 720-739. [CrossRef]

29. Walker, S.; Labeodan, T.; Boxem, G.; Maassen, W.; Zeiler, W. An assessment methodology of sustainable energy transition scenarios for realizing energy neutral neighborhoods. Appl. Energy 2018, 228, 2346-2360. [CrossRef]

30. Drijver, B.; Van Aarssen, M.; Zwart, B. De High-temperature aquifer thermal energy storage ( HT-ATES ): Sustainable and multiusable. In Proceedings of the Innostock 2012-12th International Conference on Energy Storage, Lleida, Spain, 16-18 May 2012; Volume 1, pp. 1-10.

31. Wesselink, M.; Liu, W.; Koornneef, J.; van den Broek, M. Conceptual market potential framework of high temperature aquifer thermal energy storage-A case study in the Netherlands. Energy 2018, 147, 477-489. [CrossRef]

32. Hartog, N.; Bloemendal, M.; Slingerland, E.; van Wijk, A. Duurzame Warmte Gaat Ondergronds; KWR: Utrecht, The Netherlands, 2016.

33. McKenna, R.; Fehrenbach, D.; Merkel, E. The role of seasonal thermal energy storage in increasing renewable heating shares: A techno-economic analysis for a typical residential district. Energy Build. 2019, 187, 38-49. [CrossRef] 
34. Bloemendal, M.; Hartog, N. Thermal Energy Storage with geothermal triplet for space heating and cooling. In Proceedings of the EGU General Assembly 2017, Vienna, Austria, 23-28 April 2017.

35. Bloemendal, M.; Van Wijk, A.; Hartog, N. Verwarming en koeling zonder warmtepomp met WKO-triplet. H2O 2017, 1-9.

36. HOMER Energy How HOMER Calculates the PV Array Power Output. Available online: https://www.homerenergy.com/ products/grid/docs/1.5/how_homer_calculates_the_pv_array_power_output.html (accessed on 21 November 2020).

37. IEA. The Future of Hydrogen; IEA: Paris, France, 2019.

38. Dorin. Dorin Software; Dorin: Compiobbi, Italy, 2018.

39. Ruhnau, O.; Hirth, L.; Praktiknjo, A. Time series of heat demand and heat pump efficiency for energy system modeling. Sci. Data 2019, 6, 189. [CrossRef]

40. Zuurbier, K.; van Dooren, T. Urban Waterbuffer Spangen: Resultaten; KWR: Utrecht, The Netherlands, 2019.

41. Mongird, K.; Viswanathan, V.; Balducci, P.; Alam, J.; Fotedar, V.; Koritarov, V.; Hadjerioua, B. Energy Storage Technology and Cost Characterization Report; Department of Energy: Washington, DC, USA, 2019.

42. Farahani, S.S.; Bleeker, C.; van Wijk, A.; Lukszo, Z. Hydrogen-based integrated energy and mobility system for a real-life office environment. Appl. Energy 2020, 264, 114695. [CrossRef]

43. Fraunhofer ISE. Current and Future Cost of Photovoltaics: Long-Term Scenarios for Market Development; Fraunhofer ISE: Freiburg, Germany, 2015.

44. Vartiainen, E.; Masson, G.; Breyer, C. PV LCOE in Europe 2014-2030, Final Report, 23 June 2015; 2015.

45. Goldman Sachs. NextGen Power: Solar to Transform Europe's Energy Mix; Goldman Sachs: New York, NY, USA, 2018.

46. Hydrogen Europe. Technology Roadmaps Full Pack; Hydrogen Europe: Brussels, Belgium, 2018.

47. Van Wijk, A.; Chatzimarkakis, J. Green Hydrogen for a European Green Deal-A 2x40 GW Initiative; Hydrogen Europe: Brussels, Belgium, 2020.

48. EnergiNet. The Danish Energy Agency Technology Data-Generation of Electricity and District Heating; EnergiNet: Erritsø, Denmark, 2020.

49. Fuel Cells and Hydrogen Joint Undertaking (FCHJU) STATE-OF-THE-ART AND FUTURE TARGETS (KPIS)—Large Scale FC Installations, Converting Hydrogen and Renewable Methane into Power in Various Applications (0.4-30 MW). Available online: https:/ / www.fch.europa.eu/soa-and-targets (accessed on 30 November 2020).

50. Arpagaus, C.; Bless, F.; Uhlmann, M.; Schiffmann, J.; Bertsch, S.S. High temperature heat pumps: Market overview, state of the art, research status, refrigerants, and application potentials. Energy 2018, 152, 985-1010. [CrossRef]

51. TNO; ISPT. Cost Reduction Industrial Heat Pumps (CRUISE); TNO: Amsterdam, The Netherlands, 2019.

52. Gudmundsson, O.; Thorsen, J.E.; Zhang, L. Cost analysis of district heating compared to its competing technologies. In Proceedings of the WIT Transactions on Ecology and the Environment; WIT Press: Southampton, UK, 2013; Volume 176, pp. 107-118.

53. IEA ETSAP. District Heating; IEA: Paris, France, 2013.

54. Naber, N.; Schepers, B.; Schuurbiers, M.; Rooijers, F. Een klimaatneutrale warmtevoorziening voor de gebouwde omgevingupdate 2016; 2016.

55. van Vliet, E.; de Keijzer, J.; Slingerland, E.; van Tilburg, J.; Hofsteenge, W.; Haaksma, V. Collectieve warmte naar lage temperatuurEen verkenning van mogelijkheden. 2016.

56. Hoogervorst, N. Waterstof voor de Gebouwde Omgeving; Operationalisering in de Startanalyse 2020; 2020 ; Volume 4250.

57. Milieu Centraal Energierekening. Available online: https://www.milieucentraal.nl/energie-besparen/snel-besparen/grip-op-jeenergierekening/energierekening/ (accessed on 30 November 2020).

58. Weeda, M.; Niessink, R. Waterstof als optie voor een klimaatneutrale warmtevoorziening in de bestaande bouw. 2020.

59. Fuel Cells and Hydrogen Joint Undertaking (FCH). Hydrogen Roadmap Europe; Hydrogen Europe: Brussels, Belgium, 2019.

60. CBS Gemiddelde Aardgas-en Elektriciteitslevering Woningen. 2018. Available online: https://www.cbs.nl/_/media/_excel/20 19/22/gemiddelde-aardgas-enelektriciteitslevering-woningen-2018.xls (accessed on 7 July 2020).

61. Schepers, B.; Naber, N.; van den Wijngaart, R.; van Polen, S.; van der Molen, F.; Langeveld, T.; van Bemmel, B.; Oei, A.; Hilferink, M.; van Beek, M. Functioneel Ontwerp Vesta 4.0; 2019.

62. D'Agostino, D.; Mazzarella, L. What is a Nearly zero energy building? Overview, implementation and comparison of definitions. J. Build. Eng. 2019, 21, 200-212. [CrossRef]

63. Werkgroep Discontovoet Rapport werkgroep discontovoet 2015; Den Haag. 2015.

64. Hoogervorst, N. Kosten van Klimaatneutrale Elektriciteit in 2030; 2020.

65. Planbureau voor de Leefomgeving Klimaat en Energieverkenning 2019. 2019.

66. Wang, A.; van der Leun, K.; Peters, D.; Buseman, M. European Hydrogen Backbone-How a dedicated hydrogen infrastructure can be created. 2020.

67. Roobeek, R.E. Shipping Sunshine; TU Delft: Delft, The Netherlands, 2020.

68. CBS Kerncijfers Wijken en Buurten 2018. Available online: https://www.cbs.nl/nl-nl/maatwerk/2018/30/kerncijfers-wijkenen-buurten-2018 (accessed on 20 November 2020).

69. Netbeheer Nederland. Basisinformatie over energie-infrastructuur. 2019.

70. CBS Energieverbruik Particuliere Woningen; Woningtype en Regio's. Available online: https://opendata.cbs.nl/statline/\#/CBS/ $\mathrm{nl} /$ dataset/81528NED/table?dl=3FC71 (accessed on 15 October 2020). 
71. NEDU Verbruiksprofielen-User Profiles Electricity 2018. Available online: https://www.nedu.nl/documenten/verbruiksprofielen/ (accessed on 26 November 2020).

72. van Oirsouw, P.M. Netten voor Distributie van Elektriciteit; Phase to Phase: Arnhem, The Netherlands, 2011; ISBN 978-90-817983-0-3.

73. Milieu Centraal Inductie Kookplaat: Elektrisch Koken. Available online: https://www.milieucentraal.nl/energie-besparen/ apparaten-en-verlichting/huishoudelijke-apparaten/inductie-kookplaat/ (accessed on 6 November 2020).

74. CBS Personenauto's Rijden Gemiddeld 37 Kilometer per dag. Available online: https://www.cbs.nl/nl-nl/nieuws/2012/10/ personenauto-s-rijden-gemiddeld-37-kilometer-per-dag (accessed on 6 September 2020).

75. Canals Casals, L.; Martinez-Laserna, E.; Amante García, B.; Nieto, N. Sustainability analysis of the electric vehicle use in Europe for CO2 emissions reduction. J. Clean. Prod. 2016, 127, 425-437. [CrossRef]

76. Movares. Laadstrategie Elektrisch Wegvervoer; Movares: Utrecht, The Netherlands, 2013.

77. Cuijpers, M.; Staats, M.; Bakker, W.; Hoekstra, A. Eindrapport-Toekomstverkenning Elektrisch Vervoer; ECOFYS: Utrecht, The Netherlands, 2016.

78. KNMI Klimatologie-Uurgegevens van Het Weer in Nederland. Available online: http://projects.knmi.nl/klimatologie/ uurgegevens/selectie.cgi (accessed on 21 February 2020).

79. Rijkswaterstaat Waterinfo. Available online: https://waterinfo.rws.nl/\#!/nav/index/ (accessed on 12 February 2020).

80. Hermkens, R.; Jansma, S.; van der Laan, M.; de Laat, H.; Pilzer, B.; Pulles, K. Toekomstbestendige Gasdistributienetten; Kiwa: Rijswijk, The Netherlands, 2018.

81. Kleefkens, O. Legionella and Heat Pump Water Heaters; IEA HPT: Paris, France, 2020.

82. Kleefkens, O.; Van Berkel, J.; Geelen, C.; Bos, M. Booster Heat Pump, development of test procedure and calculation methodology in order to estimate the energy performance in various domestic applications. In Proceedings of the 12th IEA Heat Pump Conference; Rotterdam, The Netherlands, 29 May 2017; p. 12.

83. Jansen, S.; Mohammadi, S.; Bokel, R. Developing a locally balanced energy system for an existing neighbourhood, using the 'Smart Urban Isle' approach. Sustain. Cities Soc. 2021, 64, 102496. [CrossRef]

84. van der Roest, E. Systeemontwerp Power to X; KWR: Utrecht, The Netherlands, 2020.

85. Wenzlaff, C.; Winterleitner, G.; Schütz, F. Controlling parameters of a mono-well high-temperature aquifer thermal energy storage in porous media, Northern Oman. Pet. Geosci. 2018, 25, 337-349. [CrossRef]

86. Marif, K.S. Counteraction of Buoyancy Flow in High Temperature Aquifer Thermal Energy Storage Systems by Applying Multiple Partially Penetrating Wells; TU Delft: Delft, The Netherlands, 2019.

87. Collignon, M.; Klemetsdal, Ø.S.; Møyner, O.; Alcanié, M.; Rinaldi, A.P.; Nilsen, H.; Lupi, M. Evaluating thermal losses and storage capacity in high-temperature aquifer thermal energy storage (HT-ATES) systems with well operating limits: Insights from a study-case in the Greater Geneva Basin, Switzerland. Geothermics 2020, 85, 101773. [CrossRef]

88. Zuurbier, K.G. Increasing Freshwater Recovery upon Aquifer Storage; Technische Universiteit Delft: Delft, The Netherlands, 2016.

89. Zuurbier, K.G.; Bakker, M.; Zaadnoordijk, W.J.; Stuyfzand, P.J. Identification of potential sites for aquifer storage and recovery (ASR) in coastal areas using ASR performance estimation methods. Hydrogeol. J. 2013, 21, 1373-1383. [CrossRef]

90. Cirkel, D.G.; Voortman, B.R.; van Veen, T.; Bartholomeus, R.P. Evaporation from (Blue-)Green Roofs: Assessing the benefits of a storage and capillary irrigation system based on measurements and modeling. Water 2018, 10, 1-21. [CrossRef]

91. Drinkwaterplatform Verzilting: Een Bedreiging Voor Ons Drinkwater? Available online: https://www.drinkwaterplatform.nl/ verzilting-drinkwater/ (accessed on 19 November 2020).

92. Geudens, P.J.J. Dutch Drinking Water Statistics 2017; 2017.

93. Hofman-Caris, R.; Bertelkamp, C.; de Waal, L.; van den Brand, T.; Hofman, J.; van der Aa, R.; van der Hoek, J. Rainwater Harvesting for Drinking Water Production: A Sustainable and Cost-Effective Solution in The Netherlands? Water 2019, 11, 511. [CrossRef]

94. Pilpola, S.; Lund, P.D. Different flexibility options for better system integration of wind power. Energy Strateg. Rev. 2019, 26, 100368. [CrossRef]

95. IEA Global EV Outlook 2020. Glob. EV Outlook 2020 2020. [CrossRef]

96. FHP project Flexible Heat and Power, Connecting heat and power networks by harnessing the complexity in distributed thermal flexibility; 2017.

97. Kirkerud, J.G.; Bolkesjø, T.F.; Trømborg, E. Power-to-heat as a flexibility measure for integration of renewable energy. Energy 2017, 128, 776-784. [CrossRef]

98. van Kranenburg, K.; de Kler, R.; Jansen, N.; van der Veen, A.; de Vos, C.; Gelevert, H. Waterstof uit Elektrolyse voor Maatschappelijk Verantwoord Netbeheer-Business Model en Business Case, 2018.

99. Kær, S.K.; Al Shakhshir, S. Power2Hydrogen WP1 Potential of Hydrogen in Energy Systems; ForskEl Energinet: Fredericia, Denmark, 2016.

100. Schilder, F.; van der Stark, M. Woonlastenneutraal Koopwoningen Verduurzamen; 2020. 